\title{
Impact of learning through credit and value creation on the efficiency of Japanese commercial banks
}

\author{
Joseph Jr. Aduba* (10) and Hiroshi Izawa
}

\author{
${ }^{*}$ Correspondence: \\ adubajj@gmail.com; \\ adubajj@fc.ritsumei.ac.jp \\ Graduate School \\ of Economics, Ritsumeikan \\ University, 1-1-1 Noji-higashi, \\ Kusatsu, Shiga 525-8577, \\ Japan
}

\begin{abstract}
This study investigates the learning curve of commercial banks regarding the efficiency of credit and value creation. However, current empirical methods for accessing the learning curve in organizations are not suitable for use in financial institutions. Considering bank-specific characteristics, we introduce a dynamic learning curve using a cost function adjusted to capture learning-by-doing in banks. Using the model, we test several hypotheses on the impact of bank intermediary experience (learning) on the efficiency of credit and value creation in Japanese commercial banks. The findings show that bank intermediary learning significantly improves the cost efficiency gain in the gross value created, total credit created, and investment. However, bank intermediary experience has no significant effect on the efficiency of the economic value created for all the banks analyzed. These findings have practical implications for evaluating cost dynamics in bank credit and value creation, risk management, lending to the real sector, and shareholder value creation.
\end{abstract}

Keywords: Bank experience, Credit creation, Investment, Japanese banks, Learning curve, Value creation

JEL Classification: G21, G32, M11

\section{Introduction}

There is a growing body of evidence suggesting that bank experience could contribute to improved bank performance. For example, bank experience has been found to significantly improve performance when: competition triggered learning (Barnett et al. 1994), merger-acquisition triggered knowledge integration and codification, thereby reducing bank failure rates (Zollo and Singh 2004), and survival-enhancing learning resulting from both success and failure experience potentially improved camel ratings (Kim et al. 2009). Recently, a study by Bush (2015) found that bank operating experience could create a mechanism that reduces the cost of producing financial services and improves the efficiency of the banking sector. The rationale is that bank production [intermediation] experience resulting from the sustained effort in value addition and asset transformation processes create knowledge that lowers the cost of producing financial services and ultimately improves bank performance [efficiency].

(c) The Author(s), 2021. Open Access This article is licensed under a Creative Commons Attribution 4.0 International License, which permits use, sharing, adaptation, distribution and reproduction in any medium or format, as long as you give appropriate credit to the original author(s) and the source, provide a link to the Creative Commons licence, and indicate if changes were made. The images or other third party material in this article are included in the article's Creative Commons licence, unless indicated otherwise in a credit line to the material. If material is not included in the article's Creative Commons licence and your intended use is not permitted by statutory regulation or exceeds the permitted use, you will need to obtain permission directly from the copyright holder. To view a copy of this licence, visit http:// creativecommons.org/licenses/by/4.0/. 
As a financial intermediary, banks create specialized commodities, such as loans and other asset portfolios, using labor and capital goods, and sell them at a price that is expected to cover the direct cost of production, including the opportunity cost (Benston and Smith 1976). The process of creating these specialized financial commodities may include risk management (Berger and Humphrey 1992), service/utility provision (Grigorian and Manole 2006), and value addition (Drake et al. 2006). These processes involve extensive documentation, information gathering, monitoring, and other inputs that incur substantial costs. Rational banks minimize these input costs and realize cost efficiency. Cost efficiency in the banking sector is sometimes associated with scale economies or bank size (Asongu and Odhiambo 2019; Berger and Mester 1997; Bossone and Lee 2004; Clark 1984). However, organizational learning literature suggests that cost efficiency could also be associated with production experience (Argote 2012).

Moreover, economies of learning (experience) differ from economies of scale in that the former explains cost efficiency in relation to accumulated knowledge in human capital or technology, whereas, the latter links cost efficiency to large scale production at a point in time (Besanko et al. 2013). In the context of loan production, for example, the efficiency gains from experience could cause a decline in the amount of monitoring labor (cost) required for the same volume of loans as the bank recognizes what information is crucial and sufficient for efficient monitoring, or as more effective screening technologies and characteristics of the applicant population are learned over time (Bush 2015). Additionally, to the extent that financial firms can capture knowledge gained from experience, changing processes, and organizational structure, policymakers would not want these experienced firms to disappear as this could lead to loss of information capital (i.e. information on existing borrowers), which has been adequately captured in these financial firms (Bush 2015).

The foregoing describes learning-by-doing, which is defined as a mechanism that reduces the costs of production by leveraging on the experience gained in the production process. This phenomenon has been quantified using the learning curve theory. The learning curve theory suggests that unit cost decreases with cumulative experience (output) at a uniform rate called the learning rate. The learning curve, which is designed to explain efficiency in the manufacturing process, has found limited application in the financial sector (banking sector). Applying the learning curve to banks poses a challenge because outputs in banks are either micro products (Clark 1984) and/or a multiproduct (Mörttinen 2005). Empirical banking literature suggests that the choice of bank outputs largely depends on the study objective. In this study, we theorized that the process of creating credit/investment (converting deposit to loans and securities), creating value (generating economic returns such as shareholder returns and gross value added), and managing risk in banks generate knowledge that may reduce the amount (cost) of inputs, labor, physical capital, and financial capital used. A policy question is whether bank experience accounts for cost efficiency in bank productions. More specifically, whether bank experience have significant impact on the efficiency of credit and value creation. The answer might improve our understanding of organizational learning in the banking sector, and more importantly, the role of bank intermediary experience in cost efficiency gain in banks. 
Motivated by the above question, we investigate the efficiency gains that might result from learning-by-doing in banks using a sample of Japanese commercial banks. ${ }^{1}$ This study has two main contributions; first, we introduce a cost function adjusted to capture learning in bank production, while considering bank-specific features. Second, and arguably the most significant contribution, we test for bank experience in credit creation, proxied by the total amount of loans and other interest-bearing investment, and value creation, proxied by economic value added (EVA) and gross value added (GVA). These proxies capture the fundamental roles of the banking sector and, in our opinion, should provide empirical outcome that is useful to both bank managers and policymakers. Our findings show that bank intermediary experience significantly accounts for cost efficiency gain in loan production, security investment, and gross value added (GVA). However, bank intermediary experience does not have significant effect on the efficiency of shareholder returns (EVA).

The remainder of this paper is organized as follows. Second section reviews relevant literature on the measurement of productivity using the learning curve theory. Third section presents the empirical approach and the data. Fourth section presents the empirical results and discussion. Final section presents the implication of the findings, recommendation, conclusion, caveat, and future research directions.

\section{Related literature}

\section{Learning in industry}

The learning curve theory proposed and applied by Wright (1936), Arrow (1962) and others, has been used to quantify cost reduction in the form of changes in unit inputs (such as labor) required in the production process. These changes in unit input requirement not attributable to fluctuations in prices of variable inputs or scale economies, could be explained by the efficiency gain over time in the working process (Aduba and Asgari 2020). This efficiency gain has been linked to the improvement in experience with routines of the production tasks, information sharing, re-engineering and redesigning, efficient production scheduling, efficient supply chain management, and strategic decision making. This phenomenon is well documented in the manufacturing industry (especially at the plant or factory level) and has been described in the literature as learning-by-doing (Arrow 1962; Bahk and Gort 1993; Balasubramanian and Lieberman 2010; Irwin and Klenow 1994; Levitt et al. 2013).

Factors that contribute to learning-by-doing in organizations are diverse. However, the knowledge generated during the production or service process seems to be the most crucial factor for organizational learning. This knowledge, scholars argue, may turn out to be a sustainable competitive advantage of the organization (Argote and Ingram 2000). Furthermore, this knowledge (know-what, know-how, know-why, and know-who) could result from within or outside the organizations and could either be process improvement or product innovations, that is, improvement in product/service quality, or both (Bahk and Gort 1993; Darr et al. 1995). Nevertheless, other deliberate actions or managerial levers such as direct labor hiring, service innovation or setting up specific units

\footnotetext{
${ }^{1}$ To our knowledge, only Bush (215) has directly measured bank performance using bank operating experience in a manner directly implying learning-by-doing.
} 
$(R \& D)$ to create technological knowledge about a production function through simple or rigorous scientific experiments, could also accelerate the learning process in organizations (Lapré and Van Wassenhove 2001).

Measuring organizational learning begins with defining and operationalizing the learning [experience] term. The literature contains several definitions of organizational learning. However, in the context of this research, the definition proposed by Fiol and Lyles (1985) appears to have the key elements needed. According to these authors, "organizational learning is the process of improving actions through better knowledge and understanding." The productivity gains that stem from improving actions through better knowledge and understanding of the production or service process in organizations is significant (Argote 2012). To measure this productivity gain through knowledge requires operationalizing the knowledge term. The initial standard measure of knowledge or experience in the learning curve formulation is the cumulative number of units produced or services delivered, defined in terms of physical, tangible output or volume of shipment in factories. However, as literature on the learning curve advanced, other variants of outputs such as defect rate, quality, number of projects completed, total-factor productivity (TFP), service time and value-added (defined in financial term) were used to measure learning-by-doing in manufacturing and service organizations. Consequently, the learning curve has been applied across several industries: in pizza franchises using cumulative pizzas produced (Darr et al. 1995), in the hotel industry using the number of available rooms (Baum and Ingram 1998), in factories using TFP (Lapré and Van Wassenhove 2001), in manufacturing at 3-digit ISIC using value-added (Aduba and Asgari 2020; Asgari and Yen 2009; Bahk and Gort 1993; Karaoz and Albeni 2005; Pramongkit et al. 2000, 2002), in hospitals using the number of successful cardiac surgeries performed (Ramanarayanan 2011), and in many other industries.

\section{Learning in the financial sector (banks)}

Two strands of literature attempt to link bank experience with improved performance. The first strand appears to connect bank performance with economies of scale and economies of specialization resulting from bank learning. For example, Benston and Smith (1976) argued that financial intermediaries like banks achieved economies of scale as a consequence of specialized skills where designed routines and information about existing consumers can be used to process other consumers and a marginal reduction in costs are expected to occur. Similarly, Clark (1988) also argued that when information on a previous borrower is reused to make other lending decisions, as long as the cost of reuse is less than the independent cost of production, reuse can help reduce the incremental cost of extending additional credits. Studies on economies of scale and scope in banking also link cost efficiency with human capital and technology embodied in financial capital infrastructure (Bossone and Lee 2004; Clark 1988). These studies do not directly measure bank learning; however, at the heart of their argument is an indirect reference to bank experience reducing costs over time. Succinctly, Arnould and Anjan (1997) posit that the ability of market participants (including banks) to appreciate the payoff implications of new security (investment) will likely depend on their experience with existing securities. 
The second strand of literature applies the theory of organizational learning to evaluate the role of bank experience in productivity improvement. Using various conceptual frameworks, these studies link bank experience with improved bank performance. Barnett et al. (1994) examined the performance of Illinois banks in terms of the year-to-year changes in returns on average assets (ROAA). The authors used a dynamic performance model that incorporates competition and takeover rate of banks in Illinois. They found that performance is negatively related to a bank's rate of being taken over only in profitable banks, and that competition can reduce a bank's ROAA by 0.08 . They also found that bank performance was related to experience (the historical path followed) and the distinctive competencies of the banks studied. Relatedly, a study of deliberate learning in the corporate acquisition of banks in the USA was undertaken by Zollo and Singh (2004). The authors defined performance as return on assets (ROA) of an acquiring bank relative to the average ROA of banks in the same geographical area as the acquiring bank, arguing that productivity could result from two sources of experience: knowledge codification and acquisition experience. Knowledge codification was operationalized as the sum of acquisition tools developed by the acquiring bank, whereas, acquisition experience was operationalized by the number of previous acquisitions completed. They found that knowledge codification significantly and positively influences acquisition performance; however, acquisition experience does not.

Kim et al. (2009) studied survival enhancing learning derived from the bank's own extreme performance experiences (success and recovery). The authors defined success experience as "the cumulative history of exceptionally strong performance of banks," and recovery experience as "a type of failure experience that occurred when banks recovered from extremely poor performance." Both experience terms were operationalized using CAMELS (capital adequacy, asset quality, management, earnings, liquidity, and sensitivity) ratings per discount factor. They argued that bank failure rate is a function of cumulative success and recovery experiences, in addition to organizational characteristics, industry and environmental conditions, operating experience, and so on. Their findings indicated that both success and failure experiences generate survival-enhancing learning in the banks, only after a certain experience is obtained. Additionally, De Young (2002) introduced a framework that allows learning to improve bank performance through the general experience and technology-based experience effects. Testing the framework on a sample of internet-based banks in comparison to traditional branching banks in the US, the author found strong evidence of the general experience effect that is available to new banking start-ups and a weak effect of technology-based experience on profitability and performance in general. Finally, Bush (2015) tested for experience effect in bank production using operating time (years since the charter was granted) as a measure of experience. The author found that cost reduces by 10.9 per cent with 10 per cent gains in the experience of a bank approximately one year old.

However, another strand of literature focuses on the development of learning frameworks for financial risk analysis, and credit misclassification and scoring using innovation or technology-based approaches, such as computing algorithms and machine learning for improving performance in the financial sector. For example, researchers have employed varieties of machine learning technologies to detect and respond to systemic risks in early fashion that have consequences for policy consolidations (Kou 
et al. 2019). Besides, regarding screening the potential credit repayment behavior of applicants, reject inference and machine learning techniques have also been deployed in financial institutions. In a recent study, Shen et al. (2020) have proposed a novel threestage reject inference learning framework using unsupervised transfer learning and a three-way decision theory that was found to demonstrate superior results for credit management applications, in comparison with other reject inference methods. Thus far, we have reviewed the various ways in which learning in the financial institutions are conceptualized. In what follows, we develop a framework based on the theory of learning curve to better understand the role of experience in bank production technologies (performance).

\section{Research methods}

The motivation behind applying the learning curve in organizations is that it can show the extent to which organizational performance improves with experience. This improvement or gain in experience is quantified using either of the three specifications: a power function (1), a production function embedded in a power function (2), and/or a production function that incorporates an experience term (3). ${ }^{2}$

$$
\begin{aligned}
& \tau_{t}=\theta \cdot X_{t}^{-\varnothing} \\
& \tau_{t}=\omega \cdot X_{t}^{\varnothing} \cdot L_{t}^{\vartheta} \\
& Q_{t}=\Delta_{t} \cdot G\left(X_{t}^{\varnothing}\right) \cdot L_{t}^{\alpha} \cdot K_{t}^{\beta}
\end{aligned}
$$

However, due to industry features, none of these empirical specifications is suitable for evaluating the learning curve in banks. Taking a different approach, we formulate an empirical model similar to those used in banking efficiency literature. Our empirical model incorporates experience term which allows learning to improve bank performance. We posit that the learning characteristics of banks can be modelled if bank experience in credit and value creation are correctly operationalized. ${ }^{3}$ We derived a costefficiency function from a Cobb-Douglass production function with three inputs: physical capital, $\psi$, deposits, and other borrowed fund, $D$, and financial capital or equity, $K$. This can be expressed as;

$$
\varnothing=\beta_{0} \psi^{\beta_{1}} \cdot D^{\beta_{2}} \cdot K^{\beta_{3}}
$$

The bank's total cost of producing output $\varnothing$ is;

$$
\not=w_{p} \psi+w_{d} D+w_{k} K
$$

If $\mathcal{C}=f(\varnothing)$, then the constrained output maximization is;

\footnotetext{
${ }^{2}$ Where $X_{t}$ is a cumulative output (a proxy of experience) represented by the chosen output. $\tau_{t}$ is the cost required to produce an additional unit of output at time, $\theta$ is the cost required to produce the first unit, $Q_{t}$ is the output level at time, $\nabla_{t}$ is the current level of knowledge and $L_{t}, W_{t}$, and $K_{t}$ are physical labour, wage rate, and capital employed, respectively.

${ }^{3}$ Our empirical model differs from that of Bush (2015) in two ways; (1) input prices, and (2) by choice of experience terms.
} 
Maximize

$$
\varnothing=\beta_{0} \psi^{\beta_{1}} \cdot D^{\beta_{2}} \cdot K^{\beta_{3}}
$$

s.t.

$$
\widehat{\ell}=w_{p} \psi+w_{d} D+w_{k} K
$$

The composite function of the constrained equation becomes;

$$
\xi=\varnothing+\eta\left(\widehat{\complement}-w_{p} \psi-w_{d} D-w_{k} K\right)
$$

where $\eta$ is the lagrangian multiplier.

It can be shown by derivative, that the bank's total cost function in (5) expressed in terms of input prices $w_{p}, w_{d}, w_{k}$ and output $\varnothing$ is ${ }^{4}$;

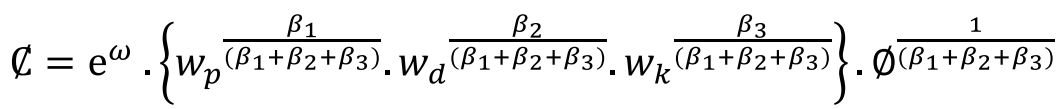

where $\mathrm{e}^{\omega}=\left\{\left(\frac{1}{\beta_{0}}\right)\left[\left(\frac{\beta_{1}}{\beta_{2}}\right)^{\beta_{2}}\left(\frac{\beta_{1}}{\beta_{3}}\right)^{\beta_{3}}+\left(\frac{\beta_{2}}{\beta_{1}}\right)^{\beta_{1}+\beta_{3}}\left(\frac{\beta_{3}}{\beta_{1}}\right)^{\beta_{3}}+\left(\frac{\beta_{1}}{\beta_{2}}\right)^{\beta_{2}}\left(\frac{\beta_{3}}{\beta_{1}}\right)^{\beta_{1}+\beta_{2}}\right]\right\}^{\frac{1}{\left(\beta_{1}+\beta_{2}+\beta_{3}\right)}}$.

For convenience, the final total cost function (9) for bank $i$ at time $t$, with bank-specific production technology adjusted for asset quality (risk) $R$ can be expressed as ${ }^{5}$;

$$
\ell_{t, i}=\mathrm{e}^{\omega} \cdot \emptyset_{t, i}^{\beta_{\emptyset}} \cdot \prod_{s} w_{s, t, i}^{\beta_{s}} \cdot R_{t, i}^{\beta_{r}}
$$

And taking the natural $\log$ of (10) will yield the empirical estimation form as;

$$
\ln \ell_{t, i}=\omega+\beta_{\emptyset} \ln \emptyset_{t, i}+\sum_{s}\left(\beta_{s}\right) \ln w_{s, t, i}+\beta_{r} \ln R_{t, i}+\varepsilon_{t, i}
$$

where $R_{i}$ is asset quality proxied by the level of non-performing loans. The level of nonperforming loan, in recent time, has become a crucial quasi-fixed input in modelling bank production used as a control variable for risky behavior in banks (J. Hughes and Mester 2014; Radić 2015). $\varepsilon_{i}$ is the stochastic term.

Following empirical literature on the learning curve, we hypothesized that unit cost will decrease with cumulative output (Aduba and Asgari 2020; Darr et al. 1995; Karaoz and Albeni 2005; Levitt et al. 2013). Therefore, from (11), a cost function that incorporates experience (learning) can be specified as;

$$
\ln \Gamma_{\mathrm{t}, \mathrm{i}}=\omega+\beta_{\varnothing} \ln \widehat{\varnothing}_{\mathrm{t}-1, \mathrm{i}}+\sum_{\mathrm{s}} \beta_{\mathrm{s}} \operatorname{lnw}_{\mathrm{s}, \mathrm{t}, \mathrm{i}}+\beta_{\mathrm{r}} \ln R_{\mathrm{t}, \mathrm{i}}+\varepsilon_{\mathrm{t}, \mathrm{i}}
$$

where $\Gamma_{t, i}=\left(\frac{Q_{t, i}}{\varnothing_{t, i}}\right)$ is the cost required to produce an additional unit of output. $\widehat{\varnothing}_{t-1, i}$ is the lagged cumulative output produce through time $t$, proxied for experience gained with bank production or financial intermediation services. Learning is measured by a

\footnotetext{
${ }^{4}$ See appendix A for the full details of the derivation.

5 The alternative to Eq.(10) will be to treat equity capital as quasi-fixed input and minimize cost condition on the level of equity K. In this case, Eq. (10) will include equity level K, but exclude cost of equity. However, using full trans-log cost function A23 in appendix A, we can derive the shadow price of equity $w_{k}$ using A24 in appendix A. Hence, we treated Eq. (10) as a full economic cost function with observable factor prices.
} 
significant negative coefficient of the experience term $\left(\beta_{\varnothing}\right)$. A significant negative $\beta_{\varnothing}$ in (12) implies unit cost decreases as experience is gained.

It is possible to approximate (12) using a cubic function to allow for the dynamic estimation of annual learning rates. ${ }^{6}$ This can be expressed as;

$$
\ln \Gamma_{t, i}=\omega+\beta_{\varnothing 1} \ln \left(\widehat{\varnothing}_{t-1, i}\right)+\beta_{\varnothing 2} \ln \left(\widehat{\varnothing}_{t-1, i}\right)^{2}+\beta_{\varnothing 3} \ln \left(\widehat{\varnothing}_{t-1, i}\right)^{3}+\sum_{s}\left(\beta_{s}\right) \ln w_{s, t, i}+\beta_{r} \ln R_{t, i}+\varepsilon_{t, i}
$$

The first derivative of (13) with respect to $\ln \widehat{\varnothing}_{t-1, i}$ yield learning elasticity $\left(\Omega_{t, i}\right)$ expressed as;

$$
\Omega_{t, i}=\frac{\partial\left(\ln \Gamma_{t, i}\right)}{\partial \widehat{\varnothing}_{t-1, i}}=\beta_{\varnothing 1}+2 . \beta_{\varnothing 2} \ln \widehat{\varnothing}_{t-1, i}+3 .\left(\beta_{\varnothing 3} \ln \widehat{\varnothing}_{t-1, i}\right)^{2}
$$

Equation (14) enables us to disentangle annual learning rates (progress ratio $\delta_{t}$ ) of bank $i$ at time $t$ using a progress function expressed in (15)

$$
\delta_{t, i}=2^{\Omega_{t-1, i}}
$$

For a progressive learning bank, $\delta_{t}$ lies between 0 and less than $1\left(0<\delta_{t}<1\right)$. For all $\delta_{t, i} \geq 1$ implies no learning has occurred in the domain of the output proxied for the cumulative experience. This means that unit cost increase as output accumulates over time.

\section{Outputs: definition and measurement of experience in bank production}

In addition to developing the appropriate framework to study the learning curve in banks, the other task is defining the appropriate outputs in banks that capture banks production experience. This is because outputs in banks depend on the study approach and the bank production technologies adopted. Defining production technology in banks begins with operationalizing the role of banks. Bank operations generally cover three important elements: profit maximization (risk management), service provision (intermediation, and utility provision), and value addition (Berger et al. 1992; Grigorian et al. 2006; Drake et al., 2006). To study the learning curve of banks, however, we combined these three elements and defined bank inputs and outputs according to the valueadded and intermediation approach. However, according to these two definitions, not all outputs qualify as experience terms.

Experience terms in learning curve studies are usually operationalized in terms of widgets of outputs and their cumulative values. This is problematic in the case of banks because outputs (the charge for services) are somewhat tricky. To overcome this difficulty, we identified bank outputs that improve when banks acquired knowledge by producing these specific outputs. ${ }^{7}$ Following this argument, we classify the role of banks in two broad ways: value creation and credit creation (investment or risk management). We illustrate this concept using Fig. 1.

\footnotetext{
${ }^{6}$ The cubic learning function is especially important for estimating the dynamic annual learning rates (Badiru 1992; Karaoz and Albeni 2005, Aduba and Asgari 2020).

7 The list of outputs considered is by no means exhaustive.
} 


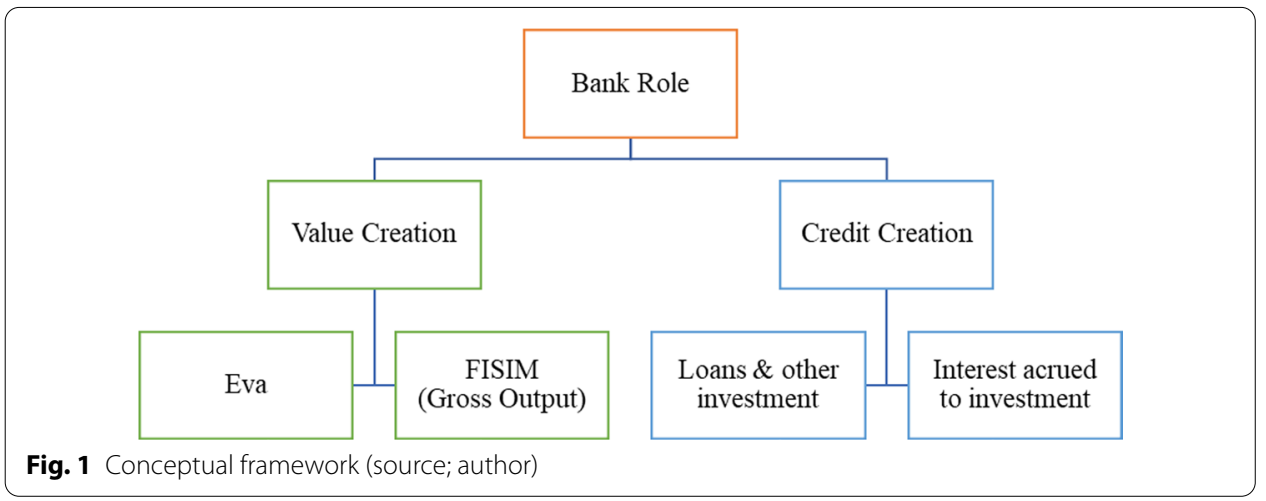

\section{Value creation}

To measure the learning curve of banks in the domain of value creation, we identified two outputs: EVA $\left(\varnothing_{\text {eva }}\right)$, and GVA (FISIM, $\left.\varnothing_{\text {fisim }}\right) .{ }^{8}$ By definition, EVA captures shareholder value (returns); EVA is arguably the most reliable value-based measurement tool used to measure shareholder value creation in banking because it adjusts for the opportunity cost of capital, reflecting the true economic profit created. Consequently, shareholder value efficiency studies in banking effectively used EVA (Amici et al. 2013; Fiordelisi 2007; Fiordelisi and Molyneux 2010; Kimball 1998; Munteanu and Brezeanu 2012; Radić, 2015; Thampy and Baheti 2012; Uyemura et al. 1996). FISIM, however, captures the gross value added to the economy from the banking sector. The FISIM approach to measuring gross output is emphasized in the value of lending service and the value of depositor service in financial institutions (Miyakawa et al. 2011). FISIM focuses on the productive activity of banks in connecting lenders to borrowers. The rationale is that a productive bank must learn to manage risks by constantly gauging the appropriate spread between interest received and interest paid out to earn a positive compensation. Analyzing these two value creation metrics using the learning curve will provide ample evidence of the cost efficiency gain in relation to bank experience in producing them.

\section{Credit creation}

Our second approach to evaluating learning in banks is through credit creation. Banks create credit by raising capital either through own-funds or through debt financing. To measure bank experience through credit creation, we proceed as follows. First, we defined $\varnothing_{T C}$ and $\varnothing_{T S}$ as the sum of the total loans created and total security investments respectively, as proxies to investigate learning by credit creation and investment. We posit that credit creation involves intensive information gathering and adequate knowledge about applicant population, risk dynamics and adequate knowledge about the interest spread that could yield positive returns. In banks, $\varnothing_{T C}$ and $\varnothing_{T S}$ cannot be cumulated because they occur naturally as cumulative minus repairment amount, reported as the consolidated amount for each fiscal year. Understandably, $\varnothing_{T C}$ fluctuates and might

\footnotetext{
${ }^{8}$ The framework for measuring EVA and FISIM as proxies of value creation in banks is described in Appendix A. FISIM stands for Financial Intermediation Services Indirect Measure. It is a bank output derived from the spread between loan interest receipts and deposit interest payments and adjusted by interbank rate.
} 
be affected by management objectives and bank risk dynamics. Nevertheless, productive banks in general, will as much as possible ensure steady growth in $\varnothing_{T C}$ and $\varnothing_{T S}$. An alternative to $\varnothing_{T C}$ and $\varnothing_{T S}$ is the total returns, generally reported as interest income $\varnothing_{T I}$. As a widget of output reported for each fiscal year, $\varnothing_{T I}$ can be cumulated and could provide a good measure of efficiency in total investment.

Inputs

This study considers three main bank inputs: physical capital (labor and value of physical assets), deposits (including all other borrowed funds) and equity capital. Although what constitutes inputs in the study of banks also depends on the definition of bank production technologies adopted, however, inputs in banks have been well defined when implementing intermediation or a value-added approach. Additionally, identifying inputs becomes even easier based on the credit and value creation role of banks as described earlier.

Researchers have argued that deposits could be considered as output. However, Hughes et al. (2001) empirically showed that the technological roles of deposits are consistent with that of input. Additionally, new bank studies have increasingly recognized the role of equity capital as input due to its ability to substitute for debts in bank financing. Following this logic, we estimated the price of equity capital and include it as the input price of capital. Moreover, like many bank studies, we also included the level of non-performing loans as asset quality to penalize banks in our sample for risky behavior. Table 1 summarizes all the outputs and inputs variables.

\section{Hypothesis development and testing}

A basic assumption underlying the learning curve theory is that learning occurs when the unit cost (of inputs) decreases as more outputs are produced over time. This implies an inverse relationship between unit cost and expanding outputs over time. Following this reasoning, we developed and tested four hypotheses related to the bank outputs (experience terms) identified above. Consequently, the decision rules (expectation and implication) of these hypotheses are based on column 5 of Table 1.

Hypothesis 1a Unit cost decreases with cumulative experience in credit creation (loans).

Hypothesis 1b Unit cost decreases with cumulative experience in credit creation (interest income).

Hypothesis 2 Unit cost decreases with cumulative experience in the gross value added (lending to the real sector and service provision).

Hypothesis 3 Unit cost decreases with cumulative experience in the economic value created (shareholder returns). 


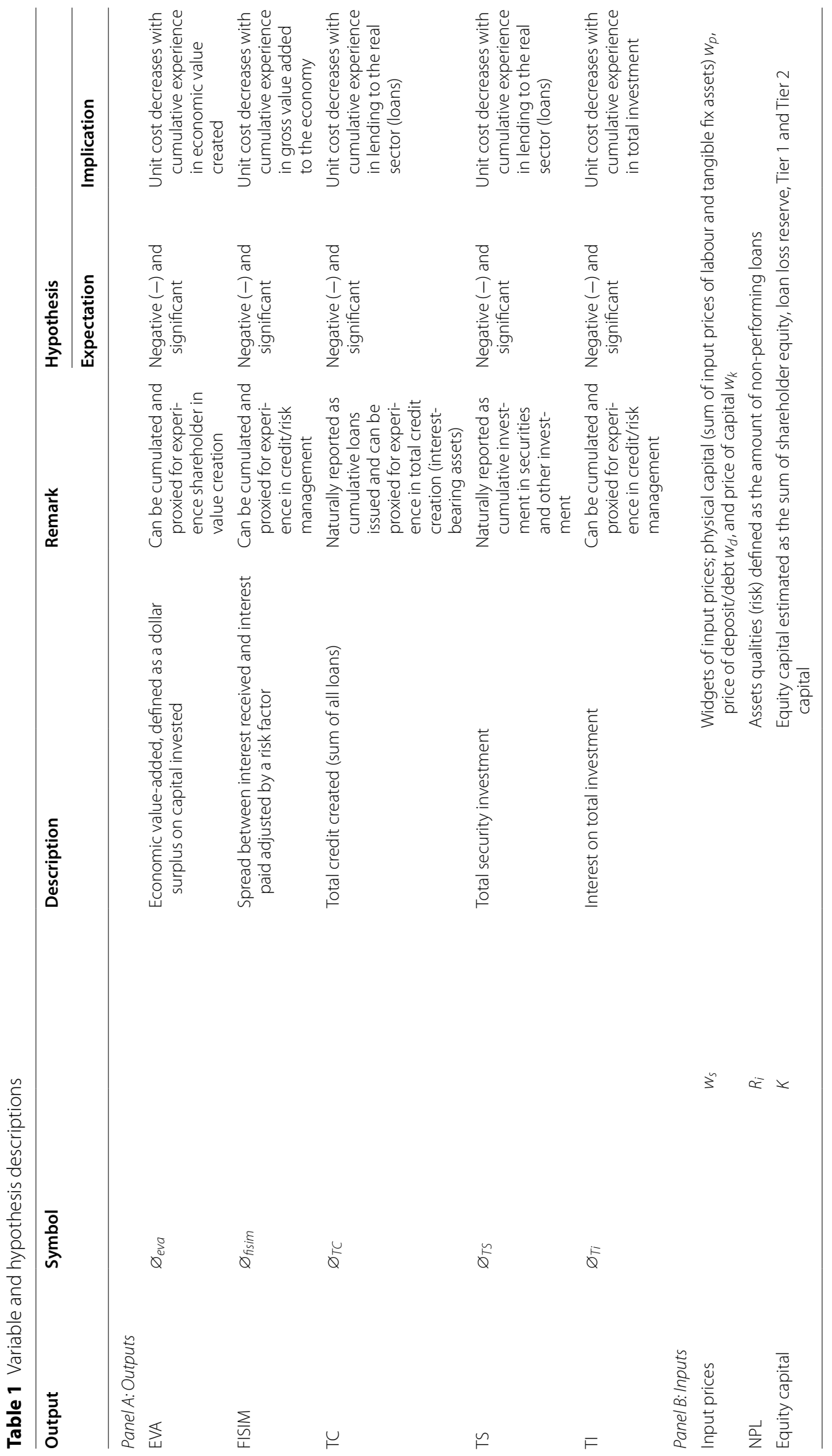



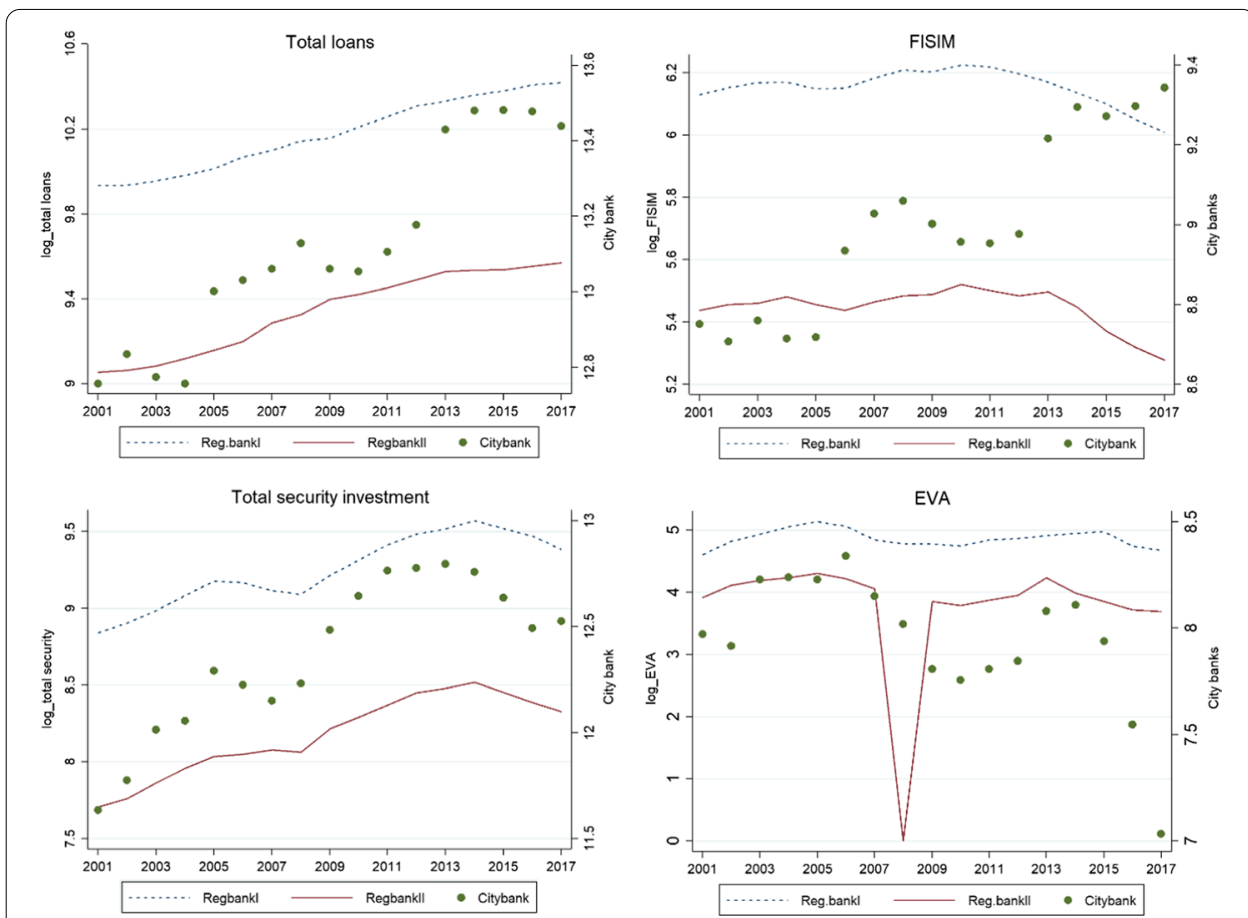

Fig. 2 The trend in some selected outputs of Japanese banks

\section{The data}

Data for this research were derived from the Japanese Bankers Association (JBA) called Zenginkyo (Japanese Bankers Association 2018). We also supplemented our data from the Financial Services Agency (FSA) official webpage. JBA publishes consolidated and unconsolidated income statement and balance sheet in English and Japanese, annually. We built panel data of all Japanese banks from the fiscal year 2001 to 2017. The initial panel data length was 1830 bank-year data (Table 1, panel B) and contained approximately 38,000 bank observations. To maintain panel data with sufficient information and degrees of freedom, we excluded banks with less than 4 years of observation, especially bankruptcy banks between 2001 and 2003. Our final sample contained a total of 250 banks with consistent data and variables of interest between 2001 and 2017 with a panel length of 1800 bank-year and approximately 30,000 bank observations.

\section{Empirical results and discussion}

\section{Summary statistics}

Appendix B shows the basic summary statistics of the variables. To see the general trend in the data, we reproduced the mean of all outputs in Fig. 2. The total credit (loans) and security investments seem to accumulate (show increasing trend) for both regional bank groups but are very unstable (fluctuates) in city banks. Credit created in city banks appears to be affected by shocks in $2002 / 2003$ and $2008 / 2009$, perhaps in response to the global financial crises during these periods. The trend in gross value created (FISIM) show bell shapes for both tiers of regional banks (a decreasing trend in recent years) but an increasing trend in city banks (with shocks similar to those observed in credit). Finally, the summary of the economic values created across bank groups shows that 
while regional bank I and II appear to have maintained constant economic value created (except in regional bank II in $2018^{9}$ ). The economic value created in city banks shows a decreasing trend.

\section{Estimation results}

This section addresses the question of whether bank experience could affect financial intermediary efficiency. Specifically, it examines how bank experience could reduce the cost of credit and value creation in Japanese commercial banks. In light of these objectives, we estimated Eq. ( 12) with five bank outputs proxied for experience in credit and value creation, namely: EVA, FISIM, total credit (loans), security investment, and total investment. This test describes the rate at which unit cost decreases as bank production (intermediation) experience improves in Japanese banks. Table 2 shows the estimated regression results of the individual learning proxy. ${ }^{10}$ The dependent variable is the ratio of the total bank cost to individual output. We hypothesized, ceteris paribus, that outputs improve (cost decrease) with experience, given that agents (bank managers) are rational and that the economy is well-behaved. We disaggregated our results using a full sample and individual bank groups to better understand the dynamics of learning in specifics and across the banking industry.

\section{Learning through value creation, credit creation and investment}

Table 2 (columns 1-2) shows the regression results of learning through value creation. We emphasize on the coefficient of individual experience terms (shaded rows). The theory suggests that a negative and significant coefficient implies learning in the domain of the output proxied for experience. Estimated experience terms show that there is no significant learning in the domain of EVA in all panels (full sample and individual bank groups). However, on the gross value added to the economy (FISIM), the result shows that bank experience significantly improves cost efficiency gain.

In terms of the credit created, the results show that there is significant evidence of learning through credit creation for all bank groups, except city banks. This implies that the city bank group does not show significant cost efficiency gain in credit creation (Table 2, column 3). However, the result of learning through investment was significant for all bank groups (column 4). The alternative measure of learning through total investment (column 5) was also significant for all bank groups. The result in column 5 describes the efficiency of total investment (the sum of interest-bearing investment represented by the total interest).

To illustrate the economic implications of the estimated learning results, we reproduced the results in Table 3 and calculated other parameters based on the learning curve theory. In particular, we estimated the implied progress ratios (learning rates) from all learning elasticities. There exists significant evidence of inefficient shareholder value creation for all bank groups. Specifically, the result shows that unit cost increases

\footnotetext{
${ }^{9}$ The actual economic value created in Regional bank II in 2008 was negative and was reduced to zero due to log transformation.

10 Our model diagnostics includes the specification test, heteroscedasticity, serial autocorrelation and cross-sectional dependence (see the relevant section for more details).
} 
Table 2 Estimated regression results of the learning model (Eq. 12)

\begin{tabular}{|c|c|c|c|c|c|}
\hline & $\begin{array}{l}\text { (1) } \\
\text { EVA }\end{array}$ & $\begin{array}{l}\text { (2) } \\
\text { FISIM (GO) }\end{array}$ & $\begin{array}{l}\text { (3) } \\
\text { Credit (tloans) }\end{array}$ & $\begin{array}{l}\text { (4) } \\
\text { Secinv }\end{array}$ & $\begin{array}{l}(5) \\
\text { TI }\end{array}$ \\
\hline \multicolumn{6}{|c|}{ Panel A: Full Sample } \\
\hline \multirow[t]{2}{*}{$\ln w_{p}$} & $1.1432^{* *}$ & $0.1157^{* *}$ & $0.3080^{* * *}$ & $0.3886^{* * *}$ & $0.2398^{* * *}$ \\
\hline & $(0.5014)$ & $(0.0485)$ & $(0.0365)$ & $(0.1071)$ & $(0.0585)$ \\
\hline \multirow[t]{2}{*}{$\ln w_{d}$} & $0.5630^{* * *}$ & 0.0795 & $0.1145^{* * *}$ & $0.1173^{*}$ & $0.1258^{* * *}$ \\
\hline & (0.1988) & $(0.0598)$ & $(0.0389)$ & $(0.0684)$ & $(0.0442)$ \\
\hline \multirow[t]{2}{*}{$\ln w_{k}$} & -0.2209 & 0.0815 & 0.0730 & 0.0597 & 0.0705 \\
\hline & $(0.3734)$ & $(0.0946)$ & $(0.0929)$ & $(0.1110)$ & $(0.0976)$ \\
\hline \multirow[t]{2}{*}{$\operatorname{InNPA}$} & -0.1623 & -0.0095 & 0.0254 & -0.0164 & 0.0338 \\
\hline & $(0.1817)$ & $(0.0124)$ & $(0.0333)$ & $(0.0817)$ & $(0.0456)$ \\
\hline \multirow{2}{*}{$\varnothing_{i t-1}$} & $0.1033^{* *}$ & $-0.4050^{* * *}$ & $-0.3910^{* * *}$ & $-0.6314^{* * *}$ & $-0.3841^{* * *}$ \\
\hline & $(0.0491)$ & $(0.0609)$ & $(0.0357)$ & $(0.0357)$ & $(0.0349)$ \\
\hline \multirow[t]{2}{*}{ _Con } & 2.2048 & $6.5630^{* * *}$ & $1.8128^{*}$ & $5.8399^{* * *}$ & 1.6899 \\
\hline & $(3.5557)$ & $(0.8573)$ & $(0.9951)$ & $(1.6061)$ & $(1.1574)$ \\
\hline Obs & 1687 & 1687 & 1687 & 1687 & 1687 \\
\hline R_square & 0.1841 & 0.5453 & 0.6336 & 0.6822 & 0.6911 \\
\hline$F$ & 16.1579 & 70.1076 & 58.9292 & 121.3465 & 79.2705 \\
\hline$p$ & 0.0000 & 0.0000 & 0.0000 & 0.0000 & 0.0000 \\
\hline rmse & 1.0850 & 0.1147 & 0.0954 & 0.1562 & 0.0957 \\
\hline \multicolumn{6}{|c|}{ Panel B: City Banks } \\
\hline \multirow[t]{2}{*}{$\ln w_{p}$} & $1.1972^{*}$ & -0.1342 & $0.5235^{* *}$ & $0.6591^{* * *}$ & $0.5378^{* * *}$ \\
\hline & $(0.4494)$ & (0.1899) & $(0.1323)$ & $(0.0975)$ & $(0.0943)$ \\
\hline \multirow[t]{2}{*}{$\ln w_{d}$} & 0.1521 & $0.4139^{* *}$ & $0.3010^{* * *}$ & $0.4229^{* * *}$ & $0.3643^{* * *}$ \\
\hline & $(0.1146)$ & $(0.1094)$ & $(0.0167)$ & $(0.0486)$ & $(0.0186)$ \\
\hline \multirow[t]{2}{*}{$\ln w_{k}$} & 0.1167 & $-0.6238^{* *}$ & $-0.4587^{* *}$ & $-0.5941^{* *}$ & $-0.5551^{* * *}$ \\
\hline & $(1.1646)$ & $(0.1661)$ & $(0.1541)$ & $(0.1434)$ & $(0.1205)$ \\
\hline \multirow[t]{2}{*}{ InNPA } & 0.3705 & $0.1319^{*}$ & 0.0487 & -0.0631 & 0.0217 \\
\hline & $(0.4150)$ & $(0.0595)$ & $(0.0299)$ & $(0.1094)$ & $(0.0616)$ \\
\hline \multirow[t]{2}{*}{$\varnothing_{i t-1}$} & $0.3070^{* *}$ & $-0.4488^{*}$ & -0.0098 & $-0.3748^{* * *}$ & $-0.0975^{* *}$ \\
\hline & $(0.0674)$ & $(0.1648)$ & $(0.0328)$ & $(0.0528)$ & $(0.0253)$ \\
\hline \multirow[t]{2}{*}{ _Con } & -11.0532 & 5.7353 & $-5.5345^{* *}$ & 2.7306 & $-3.9304^{*}$ \\
\hline & $(10.3760)$ & $(3.2280)$ & $(1.7063)$ & $(1.8650)$ & $(1.6947)$ \\
\hline Obs & 74 & 74 & 74 & 74 & 74 \\
\hline R_square & 0.6145 & 0.4830 & 0.8563 & 0.8272 & 0.8548 \\
\hline F & 14.9797 & 23.5488 & 21.9727 & 14.9797 & 127.8709 \\
\hline$p$ & 0.0000 & 0.0000 & 0.0000 & 0.0000 & 0.0000 \\
\hline rmse & 0.4101 & 0.2494 & 0.0723 & 0.1536 & 0.0870 \\
\hline \multicolumn{6}{|c|}{ Panel A: Regional Bank I } \\
\hline \multirow[t]{2}{*}{$\ln w_{p}$} & 0.9437 & $0.2676^{* * *}$ & $0.3611^{* * *}$ & $0.4180^{* * *}$ & $0.2892^{* * *}$ \\
\hline & $(0.6065)$ & $(0.0400)$ & $(0.0432)$ & $(0.1259)$ & $(0.0616)$ \\
\hline \multirow[t]{2}{*}{$\ln w_{d}$} & $0.5708^{* * *}$ & 0.0466 & $0.1091^{* *}$ & 0.1154 & $0.1243^{* *}$ \\
\hline & $(0.2008)$ & $(0.0531)$ & $(0.0426)$ & $(0.0710)$ & $(0.0472)$ \\
\hline \multirow[t]{2}{*}{$\ln w_{k}$} & -0.0950 & 0.0895 & 0.0804 & 0.0681 & 0.0782 \\
\hline & $(0.3064)$ & $(0.0886)$ & $(0.0893)$ & $(0.1049)$ & $(0.0938)$ \\
\hline \multirow[t]{2}{*}{$\operatorname{InNPA}$} & -0.0878 & -0.0095 & 0.0147 & -0.0053 & 0.0300 \\
\hline & $(0.2304)$ & $(0.0129)$ & $(0.0366)$ & $(0.0911)$ & $(0.0511)$ \\
\hline \multirow[t]{2}{*}{$\varnothing_{i t-1}$} & $0.1171^{* *}$ & $-0.4278^{* * *}$ & $-0.4435^{* * *}$ & $-0.5837^{* * *}$ & $-0.3957^{* * *}$ \\
\hline & $(0.0505)$ & $(0.1825)$ & $(0.0408)$ & $(0.0473)$ & $(0.0400)$ \\
\hline \multirow[t]{2}{*}{ _Con } & 2.2965 & $6.8054^{* * *}$ & $2.5769^{* *}$ & $5.0590^{* * *}$ & 1.8071 \\
\hline & $(4.2180)$ & $(2.3168)$ & $(1.0362)$ & $(1.8960)$ & $(1.2762)$ \\
\hline
\end{tabular}


Table 2 (continued)

\begin{tabular}{llllll}
\hline & $\mathbf{( 1 )}$ & $\mathbf{( 2 )}$ & $\mathbf{( 3 )}$ & $\mathbf{( 4 )}$ & $\mathbf{( 5 )}$ \\
& EVA & FISIM (GO) & Credit (tloans) & Secinv & TI \\
\hline Obs & 999 & 999 & 999 & 999 & 999 \\
R_square & 0.1925 & 0.5964 & 0.6557 & 0.6945 & 0.7059 \\
$F$ & 11.0512 & 61.5595 & 48.3803 & 109.2990 & 63.5233 \\
$p$ & 0.0000 & 0.0000 & 0.0000 & 0.0000 & 0.0000 \\
rmse & 1.1277 & 0.1027 & 0.0981 & 0.1481 & 0.0971 \\
Panel A: Regional Bank II & & & & & \\
Inw & $1.3381^{* *}$ & $0.2253^{* * *}$ & $0.1478^{* * *}$ & $0.2893^{*}$ & 0.0644 \\
& $(0.6588)$ & $(0.0395)$ & $(0.0344)$ & $(0.1664)$ & $(0.0627)$ \\
Inw & $0.7009^{* *}$ & 0.0388 & $0.0998^{* *}$ & 0.0993 & $0.1053^{* *}$ \\
& $(0.2908)$ & $(0.0441)$ & $(0.0431)$ & $(0.0706)$ & $(0.0485)$ \\
Inw & -0.7036 & 0.0858 & 0.0636 & 0.0550 & 0.0632 \\
& $(0.7483)$ & $(0.0958)$ & $(0.0992)$ & $(0.1188)$ & $(0.1026)$ \\
InNPA & $-0.3441^{* *}$ & -0.0174 & 0.0325 & -0.0223 & 0.0392 \\
& $(0.1411)$ & $(0.0153)$ & $(0.0274)$ & $(0.0749)$ & $(0.0386)$ \\
$\varnothing_{\text {it-1 }}$ & 0.0798 & $-0.2411^{* * *}$ & $-0.4115^{* * *}$ & $-0.7257^{* * *}$ & $-0.4315^{* * *}$ \\
& $(0.0717)$ & $(0.0426)$ & $(0.0506)$ & $(0.0279)$ & $(0.0511)$ \\
_Con & -0.0217 & $3.6700^{* * *}$ & -0.0308 & $4.7133^{* * *}$ & $-1.9340^{* *}$ \\
& $(2.6294)$ & $(0.6625)$ & $(0.9250)$ & $(1.3106)$ & $(0.9227)$ \\
Obs & 614 & 614 & 614 & 614 & 614 \\
R_square & 0.2163 & 0.6437 & 0.6663 & 0.7215 & 0.7241 \\
$F$ & 16.4636 & 49.2820 & 57.9316 & 57.8995 & 63.2943 \\
p & 0.0000 & 0.0000 & 0.0000 & 0.0000 & 0.0000 \\
rmse & 1.0539 & 0.0989 & 0.0827 & 0.1538 & 0.0843 \\
\hline Discoli-Kady & & & &
\end{tabular}

Driscoll-Kraay standard errors in parenthesis.

*** $p<0.01, * * p<0.05,{ }^{*} p<0.1$

EVA $\sim$ economic value added

FISIM(GO) Financia Intermediation Services Indirectly Measured (Gross Output)

secinv $\sim$ tota security investment,

tloans $\sim$ total loans,

$\mathrm{Tl} \sim$ Total Investment

$\varnothing_{i t-1} \sim$ learning elasticity

by approximately $23 \%$ in city banks, and $8 \%$ in regional bank I and $5 \%$ in regional bank II for every additional shareholder value created between 2001 and 2017.

On gross valued added, the result indicates that experience is correlated with gross value-added, that is, unit cost decreases as more experience is gained in producing additional gross value added, other things being equal. Quantitatively, unit cost decreases by approximately $27 \%, 26 \%$, and $15 \%$ in city banks, regional bank I and regional bank II respectively. As a proxy for learning by value creation in lending and deposit-taking (service provision), this result suggests efficient allocation of financial resources and service provisions in the Japanese banking sector.

The cost-efficiency of credit creation and investment also significantly improve with experience. In particular, the learning curve of the credit created indicates that unit cost decreases significantly for both tiers of regional banks except in city banks. The former shows $25 \%$ cost efficiency gain due to experience in loan production; we interpret this to mean learning by credit creation in Japanese regional banks. A similar result was 
Table 3 Estimated progress

\begin{tabular}{|c|c|c|c|c|c|c|}
\hline & $\begin{array}{l}\text { (1) } \\
\text { EVA }\end{array}$ & $\begin{array}{l}\text { (2) } \\
\text { FISIM (GO) }\end{array}$ & \multicolumn{2}{|l|}{$\begin{array}{l}\text { (3) } \\
\text { Credit (tloans) }\end{array}$} & $\begin{array}{l}\text { (4) } \\
\text { Secinv }\end{array}$ & $\begin{array}{l}\text { (5) } \\
\text { TI }\end{array}$ \\
\hline \multicolumn{7}{|c|}{ Panel A: Full Sample } \\
\hline$\varnothing_{i t-1}$ & $\begin{array}{l}0.1033^{* *} \\
(0.0491)\end{array}$ & $\begin{array}{l}-0.4050^{* * *} \\
(0.0609)\end{array}$ & \multicolumn{2}{|l|}{$-0.3910^{* * *}$} & $\begin{array}{l}-0.6314^{* * *} \\
(0.0357)\end{array}$ & $\begin{array}{l}-0.3841^{* * *} \\
(0.0349)\end{array}$ \\
\hline \multicolumn{5}{|c|}{ Estimated progress ratios } & & \\
\hline$\delta_{t}$ & 1.074 & 0.755 & \multicolumn{2}{|l|}{0.763} & 0.646 & 0.766 \\
\hline$\delta_{t}(\%)$ & 107.42 & 75.50 & \multicolumn{2}{|l|}{76.26} & 64.55 & 76.63 \\
\hline $100-\delta_{t}(\%)$ & -7.42 & 24.50 & \multicolumn{2}{|l|}{23.74} & 35.45 & 23.37 \\
\hline \multicolumn{5}{|c|}{ Panel B: City Banks } & & \\
\hline$\varnothing_{i t-1}$ & $\begin{array}{l}0.3070^{* *} \\
(0.0674)\end{array}$ & $\begin{array}{l}-0.4488^{*} \\
(0.1648)\end{array}$ & $\begin{array}{l}-0.0098 \\
(0.0328)\end{array}$ & $\begin{array}{l}-0.3748^{* * *} \\
(0.0528)\end{array}$ & & $\begin{array}{l}-0.0975^{* *} \\
(0.0253)\end{array}$ \\
\hline \multicolumn{7}{|c|}{ Estimated progress ratios } \\
\hline$\delta_{t}$ & 1.2371 & 0.733 & 0.993 & 0.771 & & 1.070 \\
\hline$\delta_{t}(\%)$ & 123.71 & 73.27 & 100.0 & 77.12 & & 106.99 \\
\hline $100-\delta_{t}(\%)$ & -23.71 & 26.73 & 0.00 & 22.88 & & -6.99 \\
\hline \multicolumn{7}{|c|}{ Panel A: Regional Bank I } \\
\hline$\varnothing_{i t-1}$ & $\begin{array}{l}0.1171^{* *} \\
(0.0505)\end{array}$ & $\begin{array}{l}-0.4278^{* * *} \\
(0.1825)\end{array}$ & $\begin{array}{l}-0.4435^{* * *} \\
(0.0408)\end{array}$ & $\begin{array}{l}-0.5837^{* * *} \\
(0.0473)\end{array}$ & & $\begin{array}{l}-0.3957^{* * *} \\
(0.0400)\end{array}$ \\
\hline \multicolumn{7}{|c|}{ Estimated progress ratios } \\
\hline$\delta_{t}$ & 1.085 & 0.7434 & 0.735 & 0.667 & & 0.760 \\
\hline$\delta_{t}(\%)$ & 108.46 & 74.34 & 73.53 & 66.73 & & 76.01 \\
\hline $100-\delta_{t}(\%)$ & -8.46 & 25.66 & 26.47 & 33.27 & & 23.99 \\
\hline \multicolumn{7}{|c|}{ Panel A: Regional Bank II } \\
\hline$\varnothing_{i t-1}$ & $\begin{array}{l}0.0798 \\
(0.0717)\end{array}$ & $\begin{array}{l}-0.2411^{* * *} \\
(0.0426)\end{array}$ & $\begin{array}{l}-0.4115^{* * *} \\
(0.0506)\end{array}$ & $\begin{array}{l}-0.7257^{* * *} \\
(0.0279)\end{array}$ & & $\begin{array}{l}-0.4315^{* * *} \\
(0.0511)\end{array}$ \\
\hline \multicolumn{6}{|c|}{ Estimated progress ratios } & Do not reject \\
\hline$\delta_{t}$ & 1.057 & 0.846 & 0.752 & 0.605 & & 0.7415 \\
\hline$\delta_{t}(\%)$ & 105.69 & 84.61 & 75.18 & 60.47 & & 74.15 \\
\hline $100-\delta_{t}(\%)$ & -5.69 & 15.39 & 24.82 & 39.53 & & 25.85 \\
\hline Cost implication & Inefficient & Efficient & Efficient & Efficient & & Efficient \\
\hline
\end{tabular}

Driscoll-Kraay standard errors in parenthesis.

*** $p<0.01, * * p<0.05,{ }^{*} p<0.1$

EVA $\sim$ economic value added,

FISIM(GO) Financial Intermediation Services Indirectly Measured (Gross Output)

$\mathrm{FBI} \sim$ fee based income,

tloans $\sim$ total loans,

$\mathrm{Tl} \sim$ Total Investment

$\varnothing_{i t-1} \sim$ learning elasticity 
obtained for security investments. Most importantly, the result for the overall investment shows significant cost efficiency gain due to learning by investment for all bank groups. ${ }^{11}$

\section{Dynamic learning through credit and value creation in Japanese banks}

The empirical literature on the learning curve shows that learning is dynamic and varies over time (Aduba and Asgari 2020; Karaoz and Albeni 2005; Lapré and Nembhard 2010). Similarly, it can be argued that bank learning in the domain of credit and value creation is not static. We investigate the dynamics of credit and value creation in Japanese banks using the cubic approximation of the learning model (13). This model enables us to disentangle the dynamic annual learning rates within and across bank groups. We now focus on outputs that demonstrate learning potentials by excluding the result of EVA. We estimated the annual learning rates using (15). ${ }^{12}$ In what follows, we graphically discuss the result using Fig. 3 .

The curve of the annual learning rates for gross valued added (FISIM) shows sustained learning for both tiers of regional banks for all the years analyzed. This evidence was confirmed by the lower panel of the learning curve of gross value added expressed in terms of cost efficiency gain. The result shows that cost efficiency in the gross value created improves progressively between $10-15 \%$ per annum for both tiers of regional banks. The learning curve of the gross value added for city banks also shows learning (cost efficiency gain) only within the first half of the study period (2001-2010). However, cost efficiency was completely lost 2011 onward. This might imply an increasing cost of lending or inefficient lending in relation to the cost of lending and other variable costs.

In terms of learning through credit creation, the learning curve appears to be precisely similar to the learning curve of gross value added for all bank groups. This is expected, as the volume of credit created directly influences the spread between the returns on credit and the interest payout under a fixed interest rate regime (as is the case in Japan).

The learning curve of security investment shows progressive cost-efficiency gain for both tiers of regional banks from 2001 to 2017. Again, the learning curve of security investment for city banks shows an increasing cost from 2008 to 2017. This implies that there is cost efficiency lost in this bank group in recent years. Finally, the learning curve of total investment indicates that both tiers of regional banks show sustained learning (cost efficiency gain) from 2001 to 2017 and for city banks from 2001 to 2012 only.

In sum, the results showed that learning is dynamic and varies across bank groups. All bank groups studied showed significant and progressive learning in the domain of gross value added, credit created and investment/risk management. City banks, however, appear to have been increasingly taking on riskier behavior (as explained by increasing unit cost relative to gross value added, credit and investments).

\footnotetext{
11 The caveat is that these results are based on a point estimation (overall average) of the impact of learning on efficiency gain. However, the year-to-year changes on efficiency gain (presented in the next section) resulting from learning show a better picture.

12 See Appendix E for the estimated annual learning rates (progress ratios).
} 

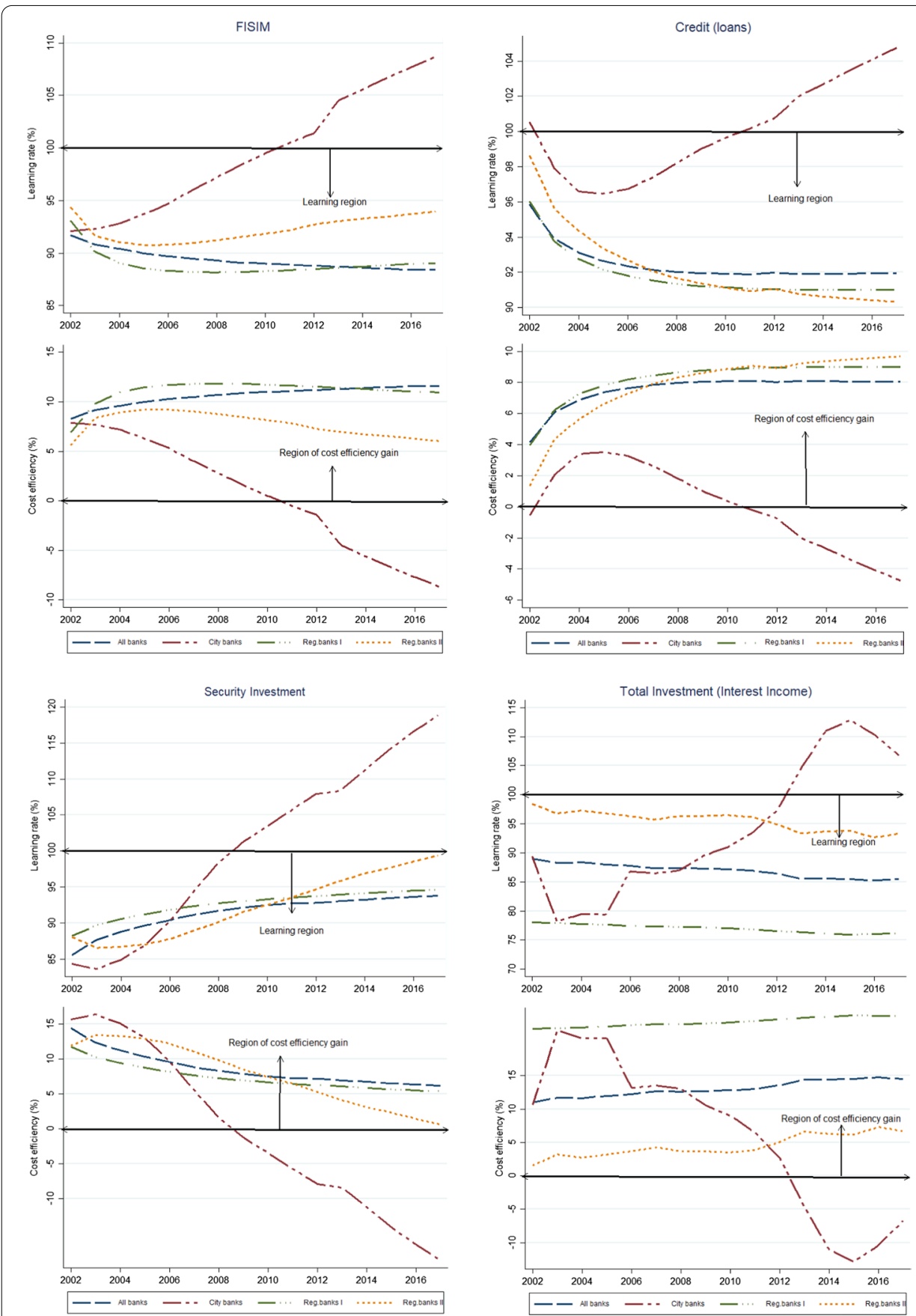

Fig. 3 Dynamic learning rates and cost efficiency in Japanese commercial banks

\section{Further discussion and policy implications}

This section discusses further insights which may be gained from the analysis of the learning curve of Japanese commercial banks. First, the findings on the efficiency of EVA (shareholder value creation) indicate that all bank groups failed to show significant cost efficiency gain. This shows that experience is not correlated with the shareholder value creation and that the unit cost of creating additional shareholder value continues 
to increase significantly, by between 6 and 24\% over the period analyzed, depending on the bank group. These findings imply inefficient shareholder value creation in Japanese commercial banks. This result agrees with an earlier study that implied significant shareholder value inefficiency in Japanese commercial banks between 1999 and 2015 (Radić, 2015). Shareholder value creation in banks is a trade-off between different bank actions and the resultant payoff of these actions. For example, while value determinants such as aggressive efficiency program, reduction of capital investment, and aggressive risktaking to increase net operating profit may be value-enhancing, they can adversely offset bank value creation through reduced customer satisfaction, increased business risk, and increased opportunity cost of capital respectively (Fiordelisi and Molyneux 2010). Additionally, economic value creation could also be affected by the presence of non-value enhancing units or branches in banks (Uyemura et al. 1996).

Although we do not directly measure this in our study, the lack of shareholder value efficiency in Japanese banks might point to the possible presence of non-value-enhancing units or branches. This is consistent with the long-standing position of the Japan Financial Services Agency (FSA), which in 2002 promoted the consolidation of financial institutions, especially the regional banks, to enhance profitability and to encourage smooth financing of SMEs. More than a decade later, Harimaya (2018) found that the Japanese regional banks are considered 'overbanked' and made a case for possible merger given the potential cost efficiency gain such unrealized consolidations and mergers could result in. In a more recent move, the FSA has taken more aggressive action to restructure struggling regional banks that it considers ailing and on the verge of collapsing (Kamei 2019). Therefore, from the viewpoint of organizational learning curve literature, our result implied that there is need to evaluate the value-enhancing actions of these banks to improve shareholder value efficiency, as well as overall efficiency.

Second, the findings on the learning curve of gross value added imply efficient lending and service provision for both tiers of regional banks. The findings also show that the city bank group failed to show cost efficiency gain in recent years. Related to this finding is the learning curve of credit and investment, which shows that both tiers of regional banks are cost-efficient in the domain of credit creation and total investment. However, city banks were not. This finding reflects the new micro and macroeconomic environment of these banks. For example, since the GFC of 2008, the city bank group have been expanding their overseas business operations in response to a domestic low-interest rate regime and declining demand for credit (loan) caused by demographic changes, a strategy that was meant to improve earning. However, the report of business operations of these bank groups shows that business profit declined between 2012 and 2018, exacerbated by the increasing overhead cost and exposure to higher credit risk in overseas markets (NRI 2020).

The findings of the learning curve of the total investment show that risk management has significantly improved in Japanese commercial banks and that other things being equal, this resulted from cumulative experience from previous investment despite the slow-growth economy. Using a new approach called GDP-at-risk, BoJ (2018) corroborated these findings when it established that Japanese banks have substantially and successfully managed risk on their information-intensive credit creation and other investments. 
This study further provides policy direction for these findings. First, it must be noted that Japanese banks have faced recurrent financial crises, which have continued to affect the recovery of the economy (Krawczyk 2005; Ogawa and Kitasaka 2000). Second, the shrinking demand for credit and accommodative monetary policy has continued to harm earnings in these banks. In light of these challenging micro and macroeconomic environments, the following policy direction may be viable.

(1) The efficiency of EVA is fundamental in banking because banks must create economic value to remain in business sustainably. Creating economic value in these banks implies identifying the drivers of economic value (profits) and handling detailed risk-level assessment and profitability measurement. Accordingly, topdown economic value strategies with clear value-enhancing metrics such as, costcutting in all financial products and units (perhaps using the so-called 'Muda principle'), redeployment of capital to superior investment opportunities after proper risk assessment, and most importantly realigning business models with existing economic and demographic conditions, must be aggressively pursued (NRI 2020; Uyemura et al. 1996). ${ }^{13}$

(2) The internationalization of city banks has exposed them to higher credit and overseas market risk as reflected in the inefficiency of credit created and investment found in this study. However, as noted by BoJ (2019), Japanese banks (especially city banks) must as a matter of priority upgrade their risk management capabilities to withstand overseas market stress and compete favorably with foreign financial institutions. This requires requisite human resources, technical know-how (learning-by-doing) and infrastructure upgrade (NRI 2020).

\section{Conclusion, caveat and future direction}

This study addresses whether bank experience affects the cost of financial intermediation. In particular, we focused on whether bank experience improves the efficiency of credit creation, investment, and value creation. Addressing these questions requires that we study the learning curve of banks for which there was no suitable empirical method. First, we introduced a dynamic cost function that incorporated learning and applied it to Japanese commercial banks to measure learning through credit creation, investment and value creation (economic profit and the efficiency of lending to the real sector and service provision). Second, we tested our hypotheses on the effect of four learning proxies in the domain of credit and value creation on performance of Japanese banks. The findings indicate that bank intermediary experience improves the efficiency of credit creation, investment, and the gross value added in both tiers of regional banks but not in city banks (especially in recent years). Bank experience does not have significant effect on the efficiency of shareholder value (economic value created) for all bank groups. These findings have practical implications for both bank managers and policymakers. On the one hand, the results are useful to bank managers in their evaluation of cost dynamics in bank credit and value creation (risk management

${ }^{13}$ Muda is a Japanese term for any unproductive or wasteful activities or those that do not add value to the larger system. 
Table 4 Regression diagnostic test

\begin{tabular}{|c|c|c|c|c|}
\hline & Pesaran (2015) & Modified Wald test & $\begin{array}{l}\text { Born and Breitung } \\
\text { (2016) }\end{array}$ & Wooldridge (2002) \\
\hline $\begin{array}{l}\text { The null } \\
\text { hypothesis } \\
\text { (H0) }\end{array}$ & $\begin{array}{l}\text { errors are weakly } \\
\text { cross-sectional } \\
\text { dependent }\end{array}$ & $\begin{array}{l}\operatorname{sigma}(i) \wedge 2=\operatorname{sigma} \wedge 2 \\
\text { for all } i\end{array}$ & $\begin{array}{l}\text { No first-order serial } \\
\text { correlation }\end{array}$ & $\begin{array}{l}\text { No first-order } \\
\text { autocorrelation }\end{array}$ \\
\hline EVA & $59.349^{* * *}$ & $140,000.0^{* * *}$ & 1.08 & 2.142 \\
\hline FISIM & $57.047^{* * *}$ & $11,334.37^{* * *}$ & $4.43^{* * *}$ & $20.88^{* * *}$ \\
\hline tloans & $41.288^{* * *}$ & $9763.27^{* * *}$ & $2.98^{* * *}$ & $30.423^{* * *}$ \\
\hline secinv & $76.832^{* * *}$ & $5989.53^{* * *}$ & $2.98^{* * *}$ & $61.735^{* * *}$ \\
\hline $\mathrm{Tl}$ & $69.368^{* * *}$ & $18,905.98^{* * *}$ & $4.54^{* * *}$ & $31.504^{* * *}$ \\
\hline
\end{tabular}

${ }^{* * *} p<0.01 ;{ }^{* *} p<0.05 ;{ }^{*} p<0.1$

and lending to the real sector). On the other hand, the findings provide insight and perhaps an alternative measure of bank performance (cost efficiency) for regulators. And finally, our findings necessitate further research on the role of bank experience in productivity (cost efficiency gain) of banks and other financial institutions.

This study has some limitations that could be addressed in future studies. First, banks in our sample faced a difficult and unstable micro and macroeconomic business environment in the period analyzed, and this may have impacted our results. Second, operationalizing bank experience is tricky because there exist many candidate variables as outputs in banks have many dimensions. Future research could explore other bank outputs that might capture bank experience.

\section{Model specification and robustness check}

To ensure consistent and robust estimates of our panel data modelling, we undertook the following procedure; first, we conducted a model specification test using a robust Hausman test. The test favors the fixed-effect model. Second, diagnostic tests suggest that our data suffer from autocorrelation, heteroskedasticity, and spatial cross-sectional dependence (see Table 4). Although robust or cluster standard error with feasible generalized least-squares (FGLS) based on the algorithm of Parks (1967), Wickens and Kmenta (1972), and Kmenta (1986) could correct these violations, our panel time dimension is smaller than the cross-sectional dimension. The FGLS approach becomes inappropriate in our case. Further, the introduction of time dummies does not correct or purge the spatial/cross-sectional dependence in our data. The fixed effect with Driscoll and Kraay standard errors was appropriate for our model as it corrected the cross-sectional dependence violation, as well as provided autocorrelation and heteroskedasticity consistent standard errors that are robust (Driscoll and Kraay 1998). We implemented this procedure following the algorithm by Hoechle (2007).

\section{Appendix A}

\section{The derivative of the cost function}

We assumed a bank production technology with three inputs (physical capital $\psi$, deposits, and other borrowed fund $D$, and financial capital or equity $K$ ) expressed as; 


$$
\varnothing=\beta_{0} \psi^{\beta_{1}} \cdot D^{\beta_{2}} \cdot K^{\beta_{3}}
$$

The total bank cost of producing output $\varnothing$ is;

$$
\not \subset=w_{p} \psi+w_{d} D+w_{k} K
$$

If $\varnothing=f(\varnothing)$, then the constrained output maximization is;

Maximize

$$
\varnothing=\beta_{0} \psi^{\beta_{1}} \cdot D^{\beta_{2}} \cdot K^{\beta_{3}}
$$

s.t.

$$
\widehat{\ell}=w_{p} \psi+w_{d} D+w_{k} K
$$

The composite function of the constrained equation becomes

$$
\xi=\emptyset+\eta\left(\widehat{\complement}-w_{p} \psi-w_{d} D-w_{k} K\right)
$$

where $\eta$ is the lagrangian multiplier.

The first-order condition ensures that the first derivative of (A5) w.r.t $\psi, D, K$ and $\eta$ equal to zero.

$$
\begin{aligned}
& \frac{\partial \xi}{\partial \psi}=\beta_{1} \frac{\varnothing}{\psi}-\eta w_{p}=0 \\
& \frac{\partial \xi}{\partial D}=\beta_{2} \frac{\varnothing}{D}-\eta w_{d}=0 \\
& \frac{\partial \xi}{\partial K}=\beta_{3} \frac{\varnothing}{K}-\eta w_{k}=0 \\
& \frac{\partial \xi}{\partial \eta}=\left(\widehat{\varnothing}-w_{p} \psi-w_{d} D-w_{k} K\right)=0
\end{aligned}
$$

Combining (A6) and (A7), expressed in terms of D yields;

$$
D=\left(\frac{w_{p}}{w_{d}} \frac{\beta_{2}}{\beta_{1}}\right) \psi
$$

Solving for $\quad D$ in (A3) yields;

$$
\varnothing=\beta_{0} \psi^{\beta_{1}} \cdot\left(\frac{w_{p}}{w_{d}} \frac{\beta_{2}}{\beta_{1}} \psi\right)^{\beta_{2}} \cdot K^{\beta_{3}} \rightarrow \varnothing=\beta_{0}\left(\frac{w_{p}}{w_{d}} \frac{\beta_{2}}{\beta_{1}}\right)^{\beta_{2}} \psi^{\beta_{1}+\beta_{2}} \cdot K^{\beta_{3}}
$$

Similarly, combining (A6) and (A8) and deriving $K$ yields;

$$
K=\frac{w_{p}}{w_{k}} \frac{\beta_{3}}{\beta_{1}} \psi
$$

Substituting ( A12) in (A11) yields; 


$$
\varnothing=\beta_{0} \psi^{\beta_{1}}\left(\frac{w_{p}}{w_{d}} \frac{\beta_{2}}{\beta_{1}} \psi\right)^{\beta_{2}} \cdot\left(\frac{w_{p}}{w_{k}} \frac{\beta_{3}}{\beta_{1}} \psi\right)^{\beta_{3}} \rightarrow \varnothing=\beta_{0}\left(\frac{w_{p}}{w_{d}} \frac{\beta_{2}}{\beta_{1}}\right)^{\beta_{2}} \cdot\left(\frac{w_{p}}{w_{k}} \frac{\beta_{3}}{\beta_{1}}\right)^{\beta_{3}} \psi^{\beta_{1}+\beta_{2}+\beta_{3}}
$$

Expressing ( A13) in terms of $\psi$ yields

$$
\begin{aligned}
& \psi=\left[\frac{1}{\left(\frac{w_{p}}{w_{d}} \frac{\beta_{2}}{\beta_{1}}\right)^{\beta_{2}}\left(\frac{w_{p}}{w_{k}} \frac{\beta_{3}}{\beta_{1}}\right)^{\beta_{3}}} \cdot\left(\frac{\varnothing}{\beta_{0}}\right)\right]^{\frac{1}{\left(\beta_{1}+\beta_{2}+\beta_{3}\right)}} \\
& \psi=\left(\frac{w_{d}}{w_{p}} \frac{\beta_{1}}{\beta_{2}}\right)^{\frac{\beta_{2}}{\left(\beta_{1}+\beta_{2}+\beta_{3}\right)}} \cdot\left(\frac{w_{k}}{w_{p}} \frac{\beta_{1}}{\beta_{3}}\right)^{\frac{\beta_{3}}{\left(\beta_{1}+\beta_{2}+\beta_{3}\right)}} \cdot\left(\frac{\varnothing}{\beta_{0}}\right)^{\frac{1}{\left(\beta_{1}+\beta_{2}+\beta_{3}\right)}}
\end{aligned}
$$

Recall that

$$
D=\left(\frac{w_{p}}{w_{d}} \frac{\beta_{2}}{\beta_{1}}\right) \cdot \psi
$$

$$
\begin{aligned}
& D=\left(\frac{w_{p}}{w_{d}} \frac{\beta_{2}}{\beta_{1}}\right)\left\{\left(\frac{w_{d}}{w_{p}} \frac{\beta_{1}}{\beta_{2}}\right)^{\frac{\beta_{2}}{\left(\beta_{1}+\beta_{2}+\beta_{3}\right)}} \cdot\left(\frac{w_{k}}{w_{p}} \frac{\beta_{1}}{\beta_{3}}\right)^{\frac{\beta_{3}}{\left(\beta_{1}+\beta_{2}+\beta_{3}\right)}} \cdot\left(\frac{\varnothing}{\beta_{0}}\right)^{\frac{1}{\left(\beta_{1}+\beta_{2}+\beta_{3}\right)}}\right\} \\
& D=\left(\frac{w_{p}}{w_{d}} \frac{\beta_{2}}{\beta_{1}}\right)^{\frac{\left(\beta_{1}+\beta_{3}\right)}{\left(\beta_{1}+\beta_{2}+\beta_{3}\right)}} \cdot\left(\frac{w_{p}}{w_{k}} \frac{\beta_{3}}{\beta_{1}}\right)^{\frac{\beta_{3}}{\left(\beta_{1}+\beta_{2}+\beta_{3}\right)}} \cdot\left(\frac{\varnothing}{\beta_{0}}\right)^{\frac{1}{\left(\beta_{1}+\beta_{2}+\beta_{3}\right)}}
\end{aligned}
$$

Recall also that $\quad K=\left(\frac{w_{p}}{w_{k}} \frac{\beta_{3}}{\beta_{1}}\right) \cdot \psi$

$$
\begin{aligned}
& K=\left(\frac{w_{p}}{w_{k}} \frac{\beta_{3}}{\beta_{1}}\right)\left\{\left(\frac{w_{d}}{w_{p}} \frac{\beta_{1}}{\beta_{2}}\right)^{\frac{\beta_{2}}{\left(\beta_{1}+\beta_{2}+\beta_{3}\right)}} \cdot\left(\frac{w_{k}}{w_{p}} \frac{\beta_{1}}{\beta_{3}}\right)^{\frac{\beta_{3}}{\left(\beta_{1}+\beta_{2}+\beta_{3}\right)}} \cdot\left(\frac{\varnothing}{\beta_{0}}\right)^{\frac{1}{\left(\beta_{1}+\beta_{2}+\beta_{3}\right)}}\right\} \\
& K=\left(\frac{w_{d}}{w_{p}} \frac{\beta_{1}}{\beta_{2}}\right)^{\frac{\beta_{2}}{\left(\beta_{1}+\beta_{2}+\beta_{3}\right)}} \cdot\left(\frac{w_{p}}{w_{k}} \frac{\beta_{3}}{\beta_{1}}\right)^{\frac{\left(\beta_{1}+\beta_{2}\right)}{\left(\beta_{1}+\beta_{2}+\beta_{3}\right)}} \cdot\left(\frac{\varnothing}{\beta_{0}}\right)^{\frac{1}{\left(\beta_{1}+\beta_{2}+\beta_{3}\right)}}
\end{aligned}
$$

Therefore, the total bank cost function in (A2) expressed in terms of input prices $w_{p}, w_{d}, w_{k}$ and the output $\varnothing$ is;

$$
\begin{aligned}
& \mathbb{C}=\left(\frac{1}{\beta_{0}}\right)^{\frac{1}{\left(\beta_{1}+\beta_{2}+\beta_{3}\right)}}\left\{w_{p}\left[\left(\frac{w_{d}}{w_{p}} \frac{\beta_{1}}{\beta_{2}}\right)^{\frac{\beta_{2}}{\left(\beta_{1}+\beta_{2}+\beta_{3}\right)}} \cdot\left(\frac{w_{k}}{w_{p}} \frac{\beta_{1}}{\beta_{3}}\right)^{\frac{\beta_{3}}{\left(\beta_{1}+\beta_{2}+\beta_{3}\right)}}\right]_{\beta_{2}}+\right. \\
& \left.w_{d}\left[\left(\frac{w_{p}}{w_{d}} \frac{\beta_{2}}{\beta_{1}} \cdot\right)^{\frac{\left(\beta_{1}+\beta_{3}\right)}{\left(\beta_{1}+\beta_{2}+\beta_{3}\right)}} \cdot\left(\frac{w_{p}}{w_{k}} \frac{\beta_{3}}{\beta_{1}}\right)^{\frac{\beta_{3}}{\left(\beta_{1}+\beta_{2}+\beta_{3}\right)}}\right]+w_{k}\left[\left(\frac{w_{d}}{w_{p}} \frac{\beta_{1}}{\beta_{2}}\right)^{\frac{\beta_{2}}{\left(\beta_{1}+\beta_{2}+\beta_{3}\right)}} \cdot\left(\frac{w_{p}}{w_{k}} \frac{\beta_{3}}{\beta_{1}}\right)^{\frac{\left(\beta_{1}+\beta_{2}\right)}{\left(\beta_{1}+\beta_{2}+\beta_{3}\right)}}\right]\right\} \cdot \phi^{\frac{1}{\left(\beta_{1}+\beta_{2}+\beta_{3}\right)}}
\end{aligned}
$$

From above, the final bank total cost function expressed in terms of input prices $w_{p}, w_{d}, w_{k}$ and output $\varnothing$ is;

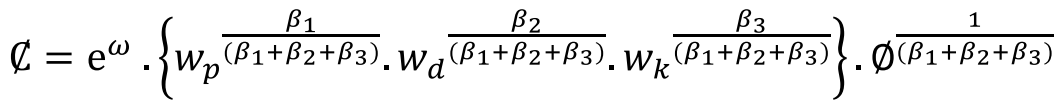

where $e^{\omega}=\left\{\left(\frac{1}{\beta_{0}}\right)\left[\left(\frac{\beta_{1}}{\beta_{2}}\right)^{\beta_{2}}\left(\frac{\beta_{1}}{\beta_{3}}\right)^{\beta_{3}}+\left(\frac{\beta_{2}}{\beta_{1}}\right)^{\beta_{1}+\beta_{3}}\left(\frac{\beta_{3}}{\beta_{1}}\right)^{\beta_{3}}+\left(\frac{\beta_{1}}{\beta_{2}}\right)^{\beta_{2}}\left(\frac{\beta_{3}}{\beta_{1}}\right)^{\beta_{1}+\beta_{2}}\right]\right\}^{\frac{1}{\left(\beta_{1}+\beta_{2}+\beta_{3}\right)}}$ 


\section{Economic value-added $\left(\mathrm{EVA}^{\mathrm{TM}}\right)$ : definition and estimation}

To estimate EVA, we follow empirical bank studies and define economic value added $\left(\varphi_{t, i}\right)$ as the economic measure of bank net operating profit adjusted for tax $\left(\Pi_{t, i}\right)$ less capital charge. The capital charge is defined as the product of capital employed $\left(\epsilon_{t}\right)$ and the estimated price of capital $\left(w_{k}\right)$ (Fiordelisi 2007; Fiordelisi and Molyneux 2010; Radić, 2015).

$$
\varphi_{t, i}=\Pi_{t, i}-w_{k} \cdot \epsilon_{t}
$$

Next, we calculated $\left(\Pi_{t, i}\right)$ and $\left(\epsilon_{t}\right)$ by accounting for bank-specific features. ${ }^{14}$ To calculate the price of capital $w_{k}$, we adopted the method proposed by Hughes et al. (2001), Fiordelisi and Molyneux (2010); and Radić (2015), by including the level of equity as a quasifixed input in a standard trans-log cost function expressed in (A23). These authors showed that the shadow price of equity provides a good measure of the opportunity cost of capital.

$$
\begin{aligned}
\ln \left(\frac{C_{i}}{\gamma_{3}}\right)= & \theta_{0}+\sum_{i} \theta_{i} \ln \varnothing_{i}+\beta_{\gamma_{1}} \ln \left(\frac{\gamma_{1}}{\gamma_{3}}\right)+\beta_{\gamma_{2}} \ln \left(\frac{\gamma_{2}}{\gamma_{3}}\right)+\tau \ln E_{k}+t_{1} T \\
& +\frac{1}{2}\left[\sum_{i} \sum_{j} \theta_{i j} \ln \varnothing_{i} \ln \varnothing_{j}+\beta_{\gamma_{11}} \ln \left(\frac{\gamma_{1}}{\gamma_{3}}\right) \ln \left(\frac{\gamma_{1}}{\gamma_{3}}\right)\right. \\
& \left.+\beta_{\gamma_{22}} \ln \left(\frac{\gamma_{2}}{\gamma_{3}}\right) \ln \left(\frac{\gamma_{2}}{\gamma_{3}}\right)+\sigma \ln E_{k} \ln E_{k}+t_{11} T^{2}\right] \\
& +\beta_{\gamma_{12}} \ln \left(\frac{\gamma_{1}}{\gamma_{3}}\right) \ln \left(\frac{\gamma_{2}}{\gamma_{3}}\right)+\sum_{i} \theta_{i \gamma_{1}} \ln \varnothing_{i} \ln \left(\frac{\gamma_{1}}{\gamma_{3}}\right)+\sum_{i} \theta_{i \gamma_{2}} \ln \varnothing_{i} \ln \left(\frac{\gamma_{2}}{\gamma_{3}}\right) \\
& +\sum_{i} \theta_{i k} \ln \varnothing_{i} \ln E_{k}+\sum_{i} \theta_{i t} T \ln \varnothing_{i} \ln E_{k}+\beta_{\gamma_{1 k}} \ln \left(\frac{\gamma_{1}}{\gamma_{3}}\right) \ln E_{k} \\
& +\beta_{\gamma_{2 k}} \ln \left(\frac{\gamma_{2}}{\gamma_{3}}\right) \ln E_{k}+\beta_{\gamma_{1 t}} T \ln \left(\frac{\gamma_{1}}{\gamma_{3}}\right)+\beta_{\gamma_{2 t}} T \ln \left(\frac{\gamma_{2}}{\gamma_{3}}\right)+\varepsilon_{t}
\end{aligned}
$$

where $\sum_{j} \beta_{\gamma_{j}}=1, \sum_{j} \beta_{\gamma_{j r}}=0 \forall r$ and $\sum_{j} \theta_{i \gamma_{j}}=0$

The price of capital $\left(w_{k}\right)$ is thus calculated by taking the negative derivative of the standard trans-log bank cost function in (A23) with respect to equity capital $\left(E_{k}\right)^{15}$;

$$
w_{k}=-\left(\frac{\partial \ln C_{i t}}{\partial \ln \epsilon_{k}}\right)
$$

where $C_{i}$ is the total cost of bank $i, \varnothing_{i}$ is output for bank $i, \gamma_{i}(i=1,2,3)$ is a vector of bank input prices, $E_{k}$ is the level of equity capital, and $T$ is the time trend. The output is the sum of four variables; loans and advances, $\varnothing_{1}$, security investment $\left(\varnothing_{2}\right)$, liquid cash $\left(\varnothing_{3}\right)$ and other interest-bearing assets $\left(\varnothing_{4}\right)$. input prices are computed as interest expense over debt $\left(\gamma_{1}\right)$, cost of labour over the total number of employees $\left(\gamma_{2}\right)$ and noninterest expense over fixed assets $\left(\gamma_{3}\right)$. We defined equity capital $E_{k}$ as the sum of shareholder equity, provision for loans loss reserve and other reserves.

\footnotetext{
${ }^{14}$ We follow standard practice found in literature and adjusted for loan loss provision, tax provision, other provisions, non-recurrent events, and security accounting to correct for accounting distortion that affect current earnings.

15 We impose homogeneity constraints in factor inputs by normalizing total cost and the other input prices by the third input price $\left(\gamma_{3}\right)$ and exclude it from the model.
} 


\section{Financial Intermediation Services Indirectly Measured (FISIM)}

FISIM is a framework for calculating financial institutions output (especially in banks) according to SNA 2008, an update to IBSC. ${ }^{16}$ FISIM recognizes only productive activities of the banking sector, focusing on the efficiency of lending and risk assessment in deposits and loans/security investment. This approach was found to enhance the computation of the gross value added in financial institutions, compared to the IBSC. FISIM can be estimated as;

$$
\begin{aligned}
& F I S I M=\text { FISIM }_{L}+\text { FISIM }_{D} \\
& \text { FISIM }=\left(r_{l}-r_{r}\right) * G_{L}+\left(r_{r}-r_{d}\right) * G_{D}
\end{aligned}
$$

where $r_{l}$ is the loan interest rate, $r_{d}$ deposit interest rate, $r_{r}$ is a reference rate, $G_{L}$ total loans and $G_{D}$ total deposits. The reference rate $r_{r}$ is taken as the interbank interest rate. The loan interest rate refers to the ratio of loan interest to total loan, and the deposit interest rate is the ratio of interest paid on loanable fund divided by total deposit.

\section{Appendix B}

See Table 5. 
Table 5 Summary of bank main activities (amount in 100millions of USD)

\begin{tabular}{|c|c|c|c|c|c|c|c|c|c|}
\hline & \multirow[t]{2}{*}{ Year } & \multicolumn{4}{|c|}{ Total loans } & \multicolumn{4}{|c|}{ Security investment } \\
\hline & & mean & sd & $\min$ & $\max$ & mean & sd & $\min$ & $\max$ \\
\hline \multirow[t]{17}{*}{ City Banks } & 2001 & 347,000 & 214,000 & 90,547 & 607,000 & 113,000 & 77,668 & 25,400 & 195,000 \\
\hline & 2002 & 375,000 & 147,000 & 206,000 & 588,000 & 130,000 & 70,675 & 48,969 & 229,000 \\
\hline & 2003 & 353,000 & 140,000 & 184,000 & 543,000 & 165,000 & 77,532 & 52,794 & 262,000 \\
\hline & 2004 & 347,000 & 143,000 & 181,000 & 555,000 & 172,000 & 77,002 & 50,410 & 237,000 \\
\hline & 2005 & 443,000 & 241,000 & 190,000 & 789,000 & 218,000 & 135,000 & 56,500 & 422,000 \\
\hline & 2006 & 456,000 & 241,000 & 192,000 & 784,000 & 204,000 & 132,000 & 53,204 & 414,000 \\
\hline & 2007 & 470,000 & 259,000 & 189,000 & 821,000 & 189,000 & 110,000 & 40,445 & 340,000 \\
\hline & 2008 & 503,000 & 269,000 & 185,000 & 846,000 & 205,000 & 138,000 & 47,597 & 396,000 \\
\hline & 2009 & 470,000 & 253,000 & 186,000 & 782,000 & 264,000 & 181,000 & 50,248 & 546,000 \\
\hline & 2010 & 467,000 & 240,000 & 185,000 & 748,000 & 310,000 & 217,000 & 57,013 & 621,000 \\
\hline & 2011 & 492,000 & 262,000 & 186,000 & 813,000 & 349,000 & 235,000 & 67,548 & 689,000 \\
\hline & 2012 & 528,000 & 284,000 & 192,000 & 889,000 & 354,000 & 234,000 & 63,537 & 692,000 \\
\hline & 2013 & 680,000 & 343,000 & 196,000 & $1,010,000$ & 360,000 & 244,000 & 55,805 & 631,000 \\
\hline & 2014 & 715,000 & 365,000 & 200,000 & $1,060,000$ & 347,000 & 230,000 & 42,841 & 585,000 \\
\hline & 2015 & 716,000 & 371,000 & 198,000 & $1,080,000$ & 307,000 & 212,000 & 33,446 & 532,000 \\
\hline & 2016 & 713,000 & 357,000 & 200,000 & $1,000,000$ & 266,000 & 175,000 & 34,732 & 454,000 \\
\hline & 2017 & 686,000 & 339,000 & 203,000 & 990,000 & 275,000 & 180,000 & 34,657 & 464,000 \\
\hline \multirow[t]{17}{*}{ Regional Bank I } & 2001 & 20,608 & 13,549 & 2360 & 72,158 & 6901 & 4536 & 548 & 19,222 \\
\hline & 2002 & 20,640 & 13,678 & 2484 & 75,181 & 7351 & 4937 & 653 & 19,821 \\
\hline & 2003 & 21,062 & 13,862 & 2487 & 77,685 & 7979 & 5326 & 828 & 21,972 \\
\hline & 2004 & 21,630 & 14,322 & 2517 & 77,785 & 8792 & 5798 & 948 & 24,005 \\
\hline & 2005 & 22,320 & 14,886 & 2672 & 81,452 & 9665 & 6571 & 992 & 26,352 \\
\hline & 2006 & 23,547 & 15,687 & 2677 & 84,137 & 9574 & 6586 & 947 & 26,348 \\
\hline & 2007 & 24,304 & 16,480 & 2645 & 89,336 & 9081 & 6285 & 993 & 27,922 \\
\hline & 2008 & 25,424 & 17,636 & 2783 & 93,397 & 8864 & 5691 & 924 & 23,758 \\
\hline & 2009 & 25,760 & 17,364 & 2831 & 89,134 & 10,025 & 6294 & 1024 & 28,229 \\
\hline & 2010 & 27,130 & 18,427 & 2931 & 92,881 & 11,074 & 6772 & 1096 & 29,382 \\
\hline & 2011 & 28,523 & 19,330 & 3040 & 98,248 & 12,247 & 7591 & 1075 & 31,072 \\
\hline & 2012 & 29,974 & 20,599 & 3099 & 105,000 & 13,135 & 8569 & 1535 & 37,300 \\
\hline & 2013 & 30,673 & 21,383 & 3084 & 107,000 & 13,575 & 8857 & 1689 & 40,975 \\
\hline & 2014 & 31,563 & 21,928 & 2956 & 108,000 & 14,343 & 8990 & 1797 & 39,948 \\
\hline & 2015 & 32,193 & 22,446 & 2971 & 108,000 & 13,610 & 8551 & 1535 & 36,977 \\
\hline & 2016 & 33,126 & 23,210 & 2967 & 110,000 & 12,963 & 8025 & 1555 & 34,003 \\
\hline & 2017 & 33,463 & 24,045 & 3121 & 115,000 & 11,879 & 7859 & 1366 & 32,415 \\
\hline
\end{tabular}


Table 5 (continued)

\begin{tabular}{|c|c|c|c|c|c|c|c|c|c|c|c|c|c|}
\hline & \multirow{2}{*}{\multicolumn{2}{|c|}{ Year }} & \multicolumn{6}{|c|}{ Total loans } & \multicolumn{5}{|c|}{ Security investment } \\
\hline & & & mean & \multicolumn{2}{|l|}{ sd } & $\min$ & \multicolumn{2}{|l|}{$\max$} & mean & sd & \multicolumn{2}{|c|}{$\min$} & $\max$ \\
\hline \multirow[t]{19}{*}{ Regional Bank I } & \multicolumn{2}{|c|}{2001} & 8543 & \multicolumn{2}{|l|}{6128} & 1763 & \multicolumn{2}{|l|}{34,877} & 2220 & 2400 & \multicolumn{2}{|c|}{419} & 14,524 \\
\hline & \multicolumn{2}{|c|}{2002} & 8627 & \multicolumn{2}{|l|}{6132} & 1750 & 35,775 & & 2346 & 2381 & 433 & & 13,507 \\
\hline & & 003 & 8798 & 6292 & & 797 & 36,084 & & 2597 & 2761 & 489 & & 16,452 \\
\hline & & 004 & 9110 & 6516 & & 850 & 36,451 & & 2855 & 2994 & 500 & & 17,286 \\
\hline & & 005 & 9477 & 6979 & & 818 & 38,755 & & 3086 & 3392 & 470 & & 19,475 \\
\hline & & 006 & 9877 & 7439 & & 761 & 40,699 & & 3129 & 3113 & 576 & & 16,764 \\
\hline & & 007 & 10,785 & 8088 & & 455 & 43,714 & & 3222 & 3246 & 675 & & 18,326 \\
\hline & & 008 & 11,223 & 9168 & & 449 & 51,756 & & 3180 & 2810 & 584 & & 14,242 \\
\hline & & 009 & 12,054 & 10,611 & & 494 & 56,874 & & 3700 & 3164 & 721 & & 15,765 \\
\hline & & 010 & 12,341 & 10,741 & & 579 & 56,852 & & 3986 & 3230 & 721 & & 15,909 \\
\hline & & $011 \quad 1$ & 12,728 & 11,35 & & 723 & 60,911 & & 4311 & 3390 & 388 & & 16,562 \\
\hline & & 012 & 13,196 & 11,655 & & 781 & 62,362 & & 4676 & 3574 & 407 & & 17,052 \\
\hline & & 013 & 13,725 & 11,756 & & 859 & 61,454 & & 4804 & 3604 & 470 & & 17,156 \\
\hline & & 014 & 13,829 & 11,546 & & 791 & 59,490 & & 5010 & 3899 & 403 & & 19,307 \\
\hline & & 015 & 13,846 & 11,985 & & 806 & 61,190 & & 4681 & 3677 & 481 & & 18,129 \\
\hline & & 016 & 14,084 & 12,385 & & 746 & 63,496 & & 4385 & 3662 & 428 & & 18,141 \\
\hline & & 017 & 14,329 & 12,678 & & 770 & 64,940 & & 4130 & 3271 & 519 & & 15,469 \\
\hline & & FISIM & & & & EVA & & & & Total In & terest & & \\
\hline & Year & mean & $n$ sd & $\min$ & $\max$ & mean & sd & $\min$ & $\max$ & mean & sd & $\min$ & $\max$ \\
\hline City Banks & 2001 & 6317 & 3687 & 1779 & 10,347 & 2897 & 2182 & 608 & 5746 & 11,954 & 8435 & 2172 & 20,517 \\
\hline & 2002 & 6046 & 3788 & 1787 & 10,798 & 2741 & 2550 & 576 & 7121 & 10,055 & 5656 & 2225 & 17,401 \\
\hline & 2003 & 6376 & 3349 & 2490 & 10,993 & 3747 & 2695 & 556 & 7570 & 9162 & 4110 & 4392 & 15,203 \\
\hline & 2004 & 6095 & 3502 & 1950 & 10,913 & 3781 & 2198 & 1475 & 56635 & 9106 & 4110 & 4183 & 14,719 \\
\hline & 2005 & 6115 & 4129 & 1012 & 10,595 & 3749 & 1798 & 2198 & 6650 & 11,476 & 5908 & 4218 & 18,007 \\
\hline & 2006 & 7594 & 6760 & 584 & 17,684 & 4176 & 1739 & 2185 & 56689 & 16,228 & 10,508 & 4648 & 31,200 \\
\hline & 2007 & 8324 & 6894 & 1463 & 18,348 & 3460 & 2143 & 1094 & $+\quad 5987$ & 17,842 & 11,310 & 4824 & 33,802 \\
\hline & 2008 & 8604 & 6757 & 2372 & 17,750 & 3036 & 1689 & 1004 & $4 \quad 5179$ & 15,209 & 9624 & 4527 & 28,864 \\
\hline & 2009 & 8123 & 5839 & 2972 & 15,644 & 2462 & 1545 & 962 & 4291 & 11,807 & 7503 & 3835 & 22,357 \\
\hline & 2010 & 7757 & 5514 & 2742 & 14,500 & 2336 & 1452 & 873 & 3970 & 11,011 & 6825 & 3669 & 20,332 \\
\hline & 2011 & 7734 & 5593 & 2566 & 14,294 & 2458 & 1370 & 1236 & $5 \quad 4041$ & 11,031 & 6874 & 3559 & 20,085 \\
\hline & 2012 & 7915 & 5704 & 3021 & 15,074 & 2552 & 1111 & 1269 & 3988 & 11,170 & 7164 & 3403 & 20,825 \\
\hline & 2013 & 10,065 & $55 \quad 5564$ & 2870 & 15,675 & 3226 & 1695 & 1474 & 5480 & 13,914 & 7849 & 3331 & 21,551 \\
\hline & 2014 & 10,885 & 356268 & 2714 & 17,571 & 3319 & 1211 & 1644 & 4540 & 15,581 & 9348 & 3296 & 25,766 \\
\hline & 2015 & 10,628 & $28 \quad 6132$ & 2576 & 16,974 & 2801 & 1082 & 1359 & 3883 & 14,830 & 8959 & 3104 & 24,610 \\
\hline & 2016 & 10,904 & 46692 & 2417 & 18,362 & 1893 & 739 & 1021 & 2625 & 15,057 & 9416 & 2828 & 25,543 \\
\hline & 2017 & 11,421 & 217306 & 2291 & 19,721 & 1134 & 576 & 426 & 1713 & 16,378 & 10,140 & 2764 & 26,946 \\
\hline
\end{tabular}


Table 5 (continued)

\begin{tabular}{|c|c|c|c|c|c|c|c|c|c|c|c|c|c|}
\hline & \multirow[b]{2}{*}{ Year } & \multicolumn{4}{|l|}{ FISIM } & \multicolumn{4}{|l|}{ EVA } & \multicolumn{4}{|c|}{ Total Interest } \\
\hline & & mean & sd & $\min$ & $\max$ & mean & sd & $\min$ & $\max$ & mean & sd & $\min$ & $\max$ \\
\hline \multirow{17}{*}{$\begin{array}{c}\text { Regional } \\
\text { Bank I }\end{array}$} & 2001 & 459 & 283 & 57 & 1558 & 100 & 108 & -292 & 603 & 588 & 367 & 66 & 1827 \\
\hline & 2002 & 470 & 290 & 59 & 1589 & 124 & 107 & -10 & 610 & 546 & 336 & 61 & 1701 \\
\hline & 2003 & 477 & 290 & 60 & 1638 & 139 & 125 & -65 & 688 & 544 & 327 & 64 & 1714 \\
\hline & 2004 & 478 & 296 & 60 & 1635 & 157 & 165 & 9 & 964 & 550 & 335 & 64 & 1722 \\
\hline & 2005 & 468 & 294 & 57 & 1580 & 170 & 176 & 13 & 1162 & 576 & 362 & 67 & 1733 \\
\hline & 2006 & 469 & 300 & 56 & 1641 & 158 & 137 & 17 & 649 & 616 & 397 & 72 & 1862 \\
\hline & 2007 & 484 & 319 & 54 & 1751 & 127 & 134 & -256 & 654 & 676 & 452 & 70 & 2291 \\
\hline & 2008 & 497 & 336 & 53 & 1871 & 119 & 271 & -65 & 2038 & 666 & 446 & 67 & 2317 \\
\hline & 2009 & 494 & 337 & 54 & 1844 & 119 & 114 & 0 & 593 & 612 & 398 & 72 & 2050 \\
\hline & 2010 & 505 & 330 & 56 & 1770 & 115 & 121 & -232 & 580 & 612 & 386 & 70 & 1937 \\
\hline & 2011 & 502 & 327 & 56 & 1746 & 127 & 116 & 9 & 615 & 603 & 383 & 68 & 1925 \\
\hline & 2012 & 491 & 319 & 57 & 1686 & 130 & 118 & 9 & 618 & 587 & 374 & 68 & 1891 \\
\hline & 2013 & 478 & 312 & 55 & 1622 & 136 & 122 & 10 & 675 & 580 & 374 & 70 & 1845 \\
\hline & 2014 & 462 & 303 & 52 & 1523 & 141 & 125 & 9 & 707 & 572 & 359 & 67 & 1774 \\
\hline & 2015 & 446 & 299 & 47 & 1444 & 145 & 118 & 9 & 630 & 566 & 357 & 65 & 1708 \\
\hline & 2016 & 424 & 292 & 43 & 1377 & 115 & 102 & 6 & 466 & 543 & 348 & 59 & 1608 \\
\hline & 2017 & 407 & 288 & 40 & 1417 & 107 & 98 & 0 & 459 & 528 & 363 & 55 & 1795 \\
\hline \multirow{17}{*}{$\begin{array}{c}\text { Regional } \\
\text { Bank II }\end{array}$} & 2001 & 230 & 148 & 56 & 808 & 50 & 64 & -8 & 409 & 257 & 163 & 61 & 903 \\
\hline & 2002 & 234 & 148 & 61 & 806 & 61 & 58 & -2 & 333 & 246 & 154 & 61 & 845 \\
\hline & 2003 & 235 & 149 & 61 & 800 & 66 & 56 & 10 & 318 & 246 & 156 & 61 & 846 \\
\hline & 2004 & 240 & 156 & 59 & 804 & 69 & 55 & 6 & 263 & 254 & 167 & 59 & 889 \\
\hline & 2005 & 234 & 149 & 57 & 774 & 74 & 59 & 14 & 293 & 259 & 170 & 57 & 896 \\
\hline & 2006 & 230 & 152 & 54 & 785 & 68 & 66 & 8 & 364 & 273 & 191 & 57 & 1039 \\
\hline & 2007 & 236 & 155 & 58 & 799 & 58 & 63 & -6 & 287 & 304 & 216 & 72 & 1168 \\
\hline & 2008 & 241 & 172 & 58 & 915 & -2 & 201 & -1218 & 183 & 304 & 218 & 74 & 1109 \\
\hline & 2009 & 242 & 181 & 56 & 959 & 47 & 49 & 4 & 226 & 296 & 225 & 70 & 1166 \\
\hline & 2010 & 250 & 194 & 58 & 984 & 44 & 55 & -37 & 214 & 294 & 225 & 69 & 1073 \\
\hline & 2011 & 245 & 190 & 56 & 966 & 48 & 49 & -8 & 202 & 283 & 220 & 66 & 1072 \\
\hline & 2012 & 241 & 183 & 56 & 931 & 52 & 52 & 0 & 242 & 279 & 214 & 67 & 1051 \\
\hline & 2013 & 244 & 177 & 56 & 889 & 69 & 122 & 7 & 733 & 297 & 266 & 69 & 1502 \\
\hline & 2014 & 232 & 168 & 53 & 850 & 54 & 43 & 7 & 159 & 274 & 185 & 67 & 875 \\
\hline & 2015 & 215 & 159 & 49 & 795 & 47 & 38 & 4 & 161 & 259 & 180 & 61 & 855 \\
\hline & 2016 & 204 & 150 & 44 & 756 & 41 & 31 & 5 & 120 & 245 & 169 & 55 & 821 \\
\hline & 2017 & 196 & 144 & 41 & 732 & 40 & 33 & 5 & 132 & 235 & 163 & 52 & 791 \\
\hline
\end{tabular}

\section{Appendix C}

See Table 6 and Fig. 4. 


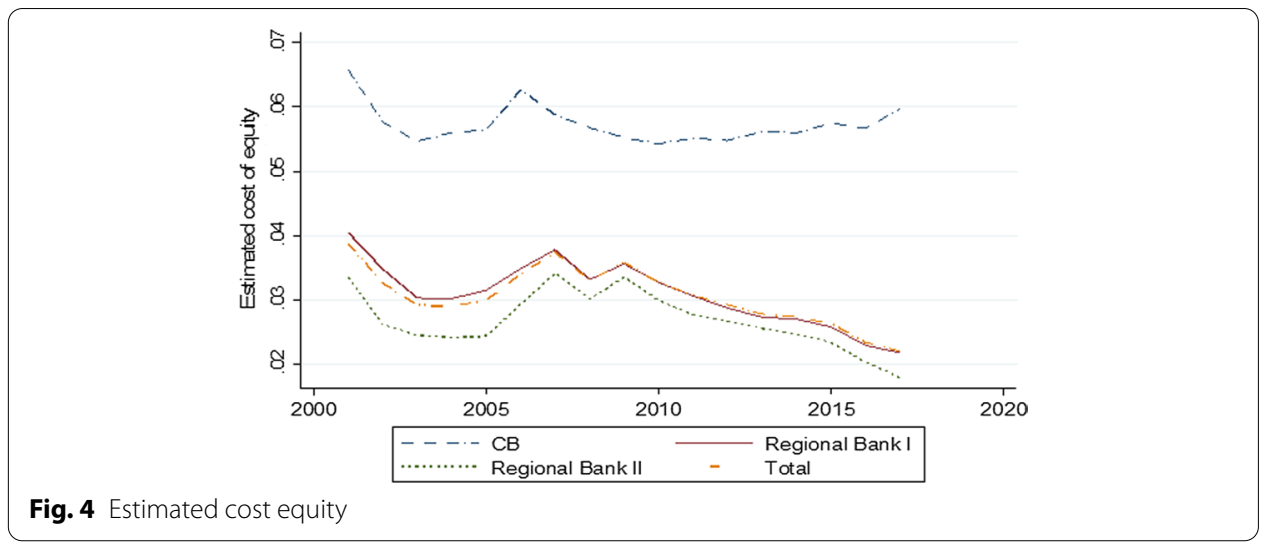

Table 6 Regression result of the estimated Trans-log cost function (Eq. A23)

\begin{tabular}{|c|c|c|c|c|c|c|c|}
\hline $\ln T C$ & Coef & St.Err & $t$-value & p-value & [95\% Conf & Interval] & Sig \\
\hline $\ln \varnothing$ & 2.1343 & 0.1325 & 16.11 & 0.000 & 1.875 & 2.394 & $* * *$ \\
\hline $0.5^{*}\left(\ln \varnothing^{2}\right)$ & -0.0052 & 0.0123 & -0.42 & 0.674 & -0.029 & 0.019 & \\
\hline $\ln w_{1}$ & -0.0740 & 0.0453 & -1.63 & 0.102 & -0.163 & 0.015 & \\
\hline $\ln w_{2}$ & 0.0631 & 0.0344 & 1.83 & 0.067 & -0.004 & 0.131 & $*$ \\
\hline $\ln E_{k}$ & 0.0162 & 0.0818 & 0.20 & 0.843 & -0.144 & 0.176 & \\
\hline $\mathrm{t}$ & -0.0090 & 0.0056 & -1.61 & 0.107 & -0.020 & 0.002 & \\
\hline $0.5 \times\left(\ln w_{1}\right)^{2}$ & 0.0102 & 0.0052 & 1.96 & 0.050 & 0.000 & 0.020 & * \\
\hline $0.5 \times \ln w_{2}{ }^{2}$ & 0.0169 & 0.0032 & 5.26 & 0.000 & 0.011 & 0.023 & $* * *$ \\
\hline $0.5 \times\left(E_{k}\right)^{2}$ & -0.0078 & 0.0012 & -6.61 & 0.000 & -0.010 & -0.005 & $* * *$ \\
\hline $0.5 \times T^{2}$ & 0.0006 & 0.0001 & 6.30 & 0.000 & 0.000 & 0.001 & $* * *$ \\
\hline $\ln \varnothing \times \ln w_{1}$ & 0.0051 & 0.0053 & 0.96 & 0.338 & -0.005 & 0.016 & \\
\hline $\ln \varnothing \times \ln w_{2}$ & -0.0235 & 0.0068 & -3.47 & 0.001 & -0.037 & -0.010 & $* * *$ \\
\hline $\ln \varnothing \times \ln E_{k}$ & 0.0021 & 0.0050 & 0.41 & 0.682 & -0.008 & 0.012 & \\
\hline $\ln \varnothing \times t$ & 0.0010 & 0.0003 & 3.20 & 0.001 & 0.000 & 0.002 & $* * *$ \\
\hline $\ln w_{1} \times \ln w_{2}$ & 0.0059 & 0.0031 & 1.87 & 0.061 & -0.000 & 0.012 & $*$ \\
\hline $\ln w_{1} \times \ln E_{k}$ & -0.0094 & 0.0052 & -1.81 & 0.071 & -0.020 & 0.001 & $*$ \\
\hline $\ln w_{2} \times \ln E_{k}$ & 0.0159 & 0.0067 & 2.38 & 0.017 & 0.003 & 0.029 & $* *$ \\
\hline $\ln w_{1} \times t$ & -0.0003 & 0.0005 & -0.54 & 0.591 & -0.001 & 0.001 & \\
\hline $\ln w_{2} \times t$ & -0.0026 & 0.0003 & -7.68 & 0.000 & -0.003 & -0.002 & $* * *$ \\
\hline Cons. & -0.9030 & 0.6352 & -1.42 & 0.155 & -2.148 & 0.342 & \\
\hline$/ m u$ & -2.7213 & 17.0605 & -0.16 & 0.873 & -36.159 & 30.717 & \\
\hline /Insigma2 & -1.6087 & 5.9322 & -0.27 & 0.786 & -13.236 & 10.018 & \\
\hline /ilgtgamma & 5.3698 & 5.9595 & 0.90 & 0.368 & -6.311 & 17.050 & \\
\hline sigma2 & 0.200144 & 1.1873 & & & $1.79 \mathrm{E}-06$ & $22,432.45$ & \\
\hline gamma & 0.995367 & 0.027485 & & & 0.001814 & 1 & \\
\hline sigma_u2 & 0.199216 & 1.1873 & & & -2.12785 & 2.526281 & \\
\hline sigma_v2 & 0.000927 & $3.24 \mathrm{E}-05$ & & & 0.000864 & 0.000991 & \\
\hline Mean dependent var & 29.4652 & & & SD dependent var & 2.2258 & & \\
\hline Number of obs & 1800 & & & Chi - square & $609,337.6989$ & & \\
\hline Prob > chi2 & 0.0000 & & & Akaike crit. (AIC) & -6994.4018 & & \\
\hline
\end{tabular}

*** $p<0.01,{ }^{* *} p<0.05,{ }^{*} p<0.1$

\section{Appendix D}

See Table 7. 


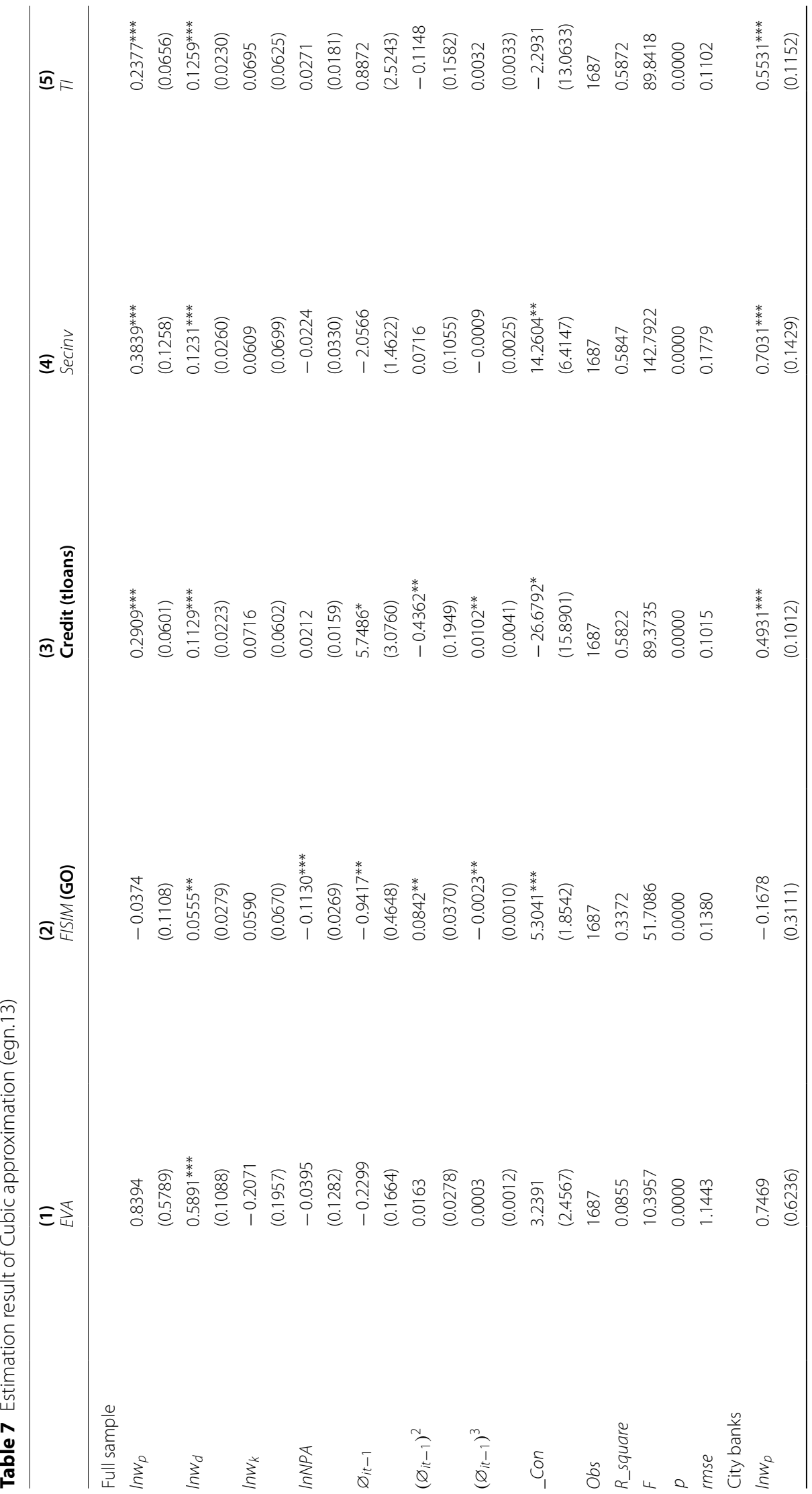




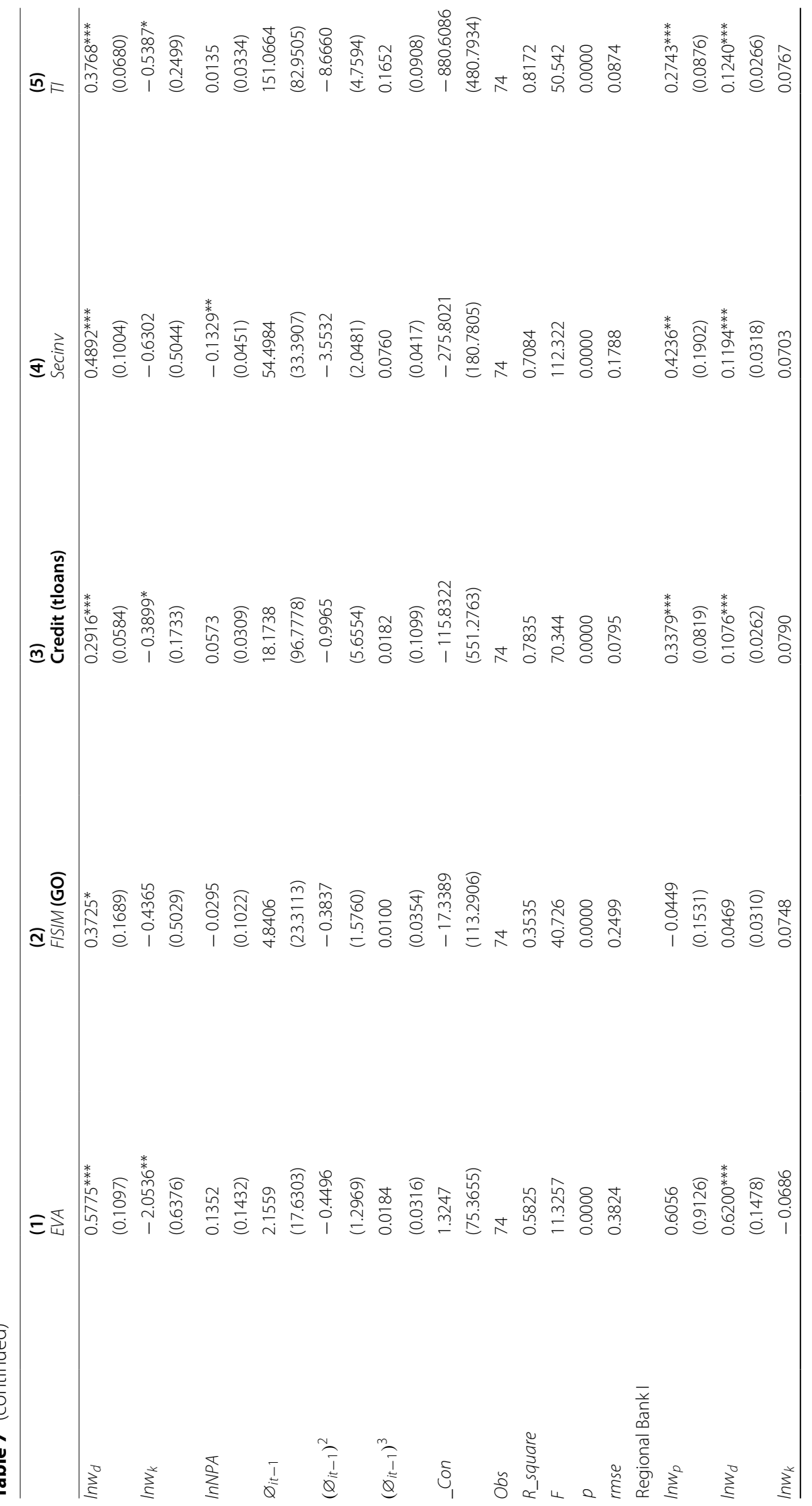




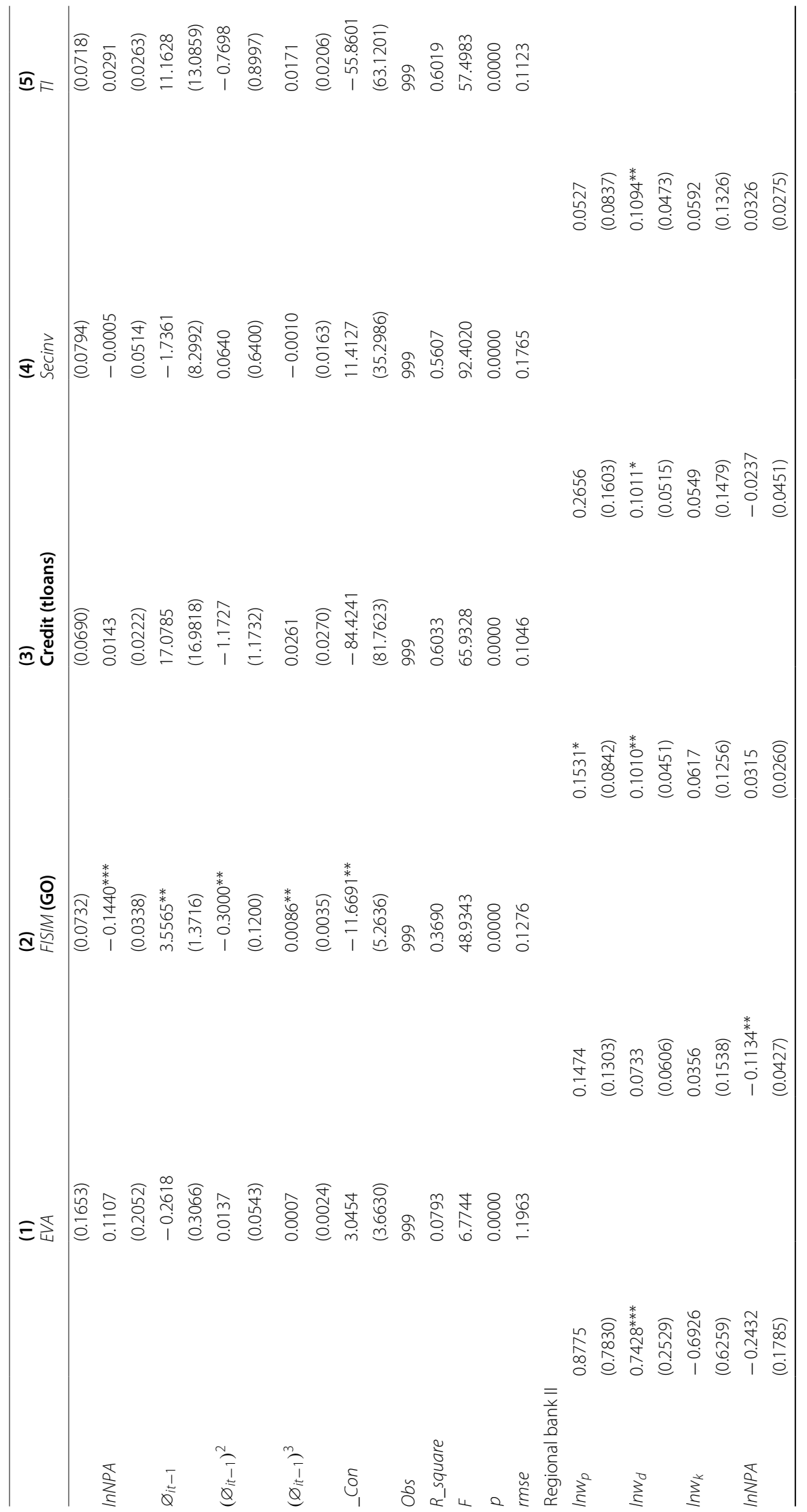




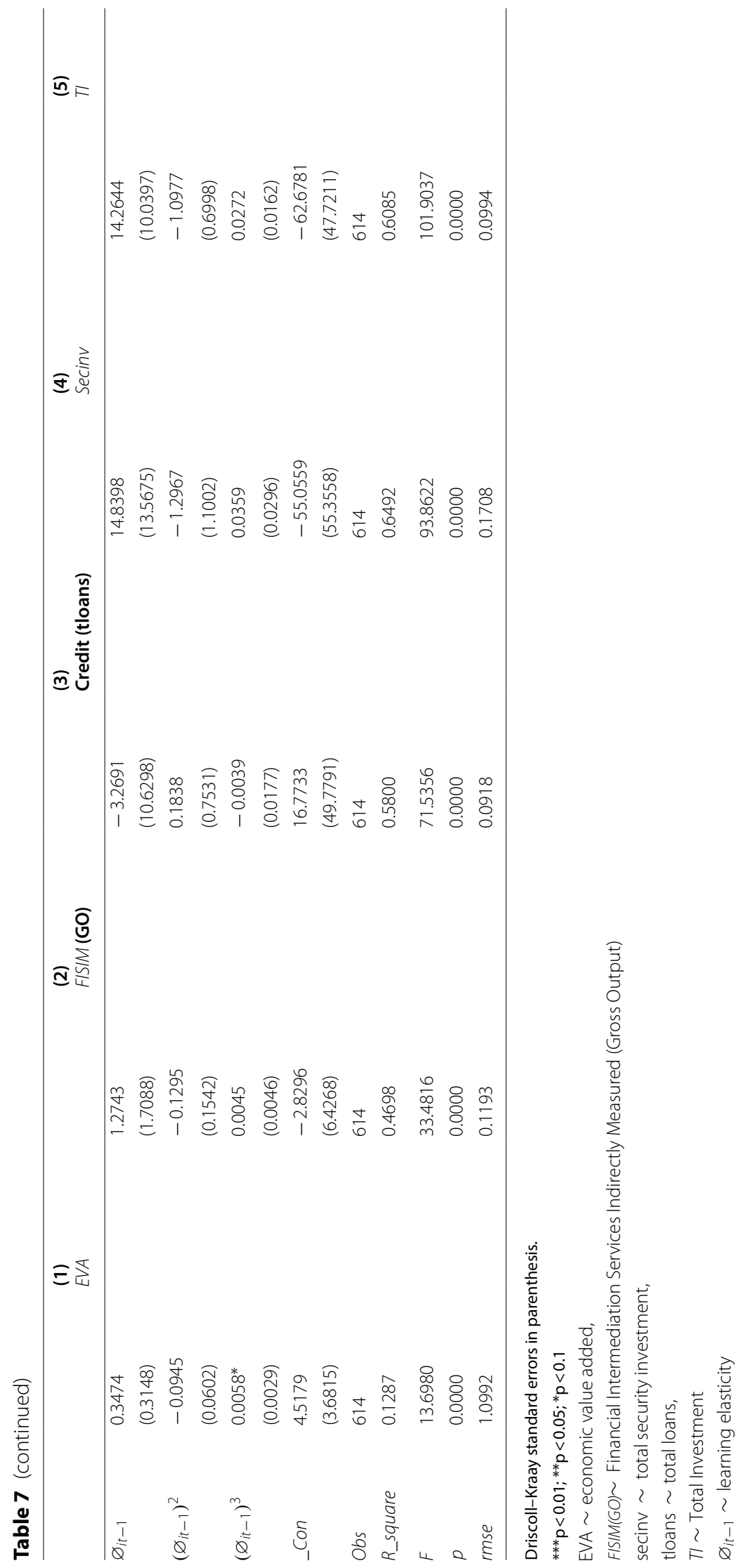




\section{Appendix E}

See Table 8.

Table 8 Estimated progress ratios

\begin{tabular}{|c|c|c|c|c|c|c|}
\hline Bank category & Year & EVA & FISIM & TC & SI & $\mathrm{TI}$ \\
\hline \multirow[t]{16}{*}{ All banks } & 2002 & 1.0799 & 0.9170 & 0.9585 & 0.8558 & 0.8895 \\
\hline & 2003 & 1.1171 & 0.9080 & 0.9390 & 0.8770 & 0.8831 \\
\hline & 2004 & 1.1359 & 0.9040 & 0.9313 & 0.8878 & 0.8834 \\
\hline & 2005 & 1.1500 & 0.9000 & 0.9264 & 0.8967 & 0.8801 \\
\hline & 2006 & 1.1613 & 0.8970 & 0.9236 & 0.9045 & 0.8779 \\
\hline & 2007 & 1.1710 & 0.8950 & 0.9214 & 0.9119 & 0.8736 \\
\hline & 2008 & 1.1769 & 0.8930 & 0.9202 & 0.9171 & 0.8739 \\
\hline & 2009 & 1.1809 & 0.8910 & 0.9195 & 0.9218 & 0.8733 \\
\hline & 2010 & 1.1849 & 0.8900 & 0.9191 & 0.9248 & 0.8719 \\
\hline & 2011 & 1.1886 & 0.8890 & 0.9189 & 0.9275 & 0.8696 \\
\hline & 2012 & 1.1914 & 0.8880 & 0.9197 & 0.9281 & 0.8643 \\
\hline & 2013 & 1.1946 & 0.8870 & 0.9190 & 0.9305 & 0.8556 \\
\hline & 2014 & 1.1988 & 0.8860 & 0.9190 & 0.9328 & 0.8557 \\
\hline & 2015 & 1.2026 & 0.8850 & 0.9193 & 0.9347 & 0.8549 \\
\hline & 2016 & 1.2056 & 0.8840 & 0.9194 & 0.9365 & 0.8525 \\
\hline & 2017 & 1.2075 & 0.8840 & 0.9196 & 0.9379 & 0.8552 \\
\hline \multirow[t]{16}{*}{ City banks } & 2002 & 0.7213 & 0.9210 & 1.0054 & 0.8436 & 0.8934 \\
\hline & 2003 & 0.8699 & 0.9230 & 0.9791 & 0.8362 & 0.7822 \\
\hline & 2004 & 1.0954 & 0.9280 & 0.9661 & 0.8494 & 0.7943 \\
\hline & 2005 & 1.2989 & 0.9370 & 0.9647 & 0.8698 & 0.7940 \\
\hline & 2006 & 1.4746 & 0.9470 & 0.9674 & 0.9030 & 0.8683 \\
\hline & 2007 & 1.6560 & 0.9600 & 0.9738 & 0.9445 & 0.8649 \\
\hline & 2008 & 1.7928 & 0.9720 & 0.9820 & 0.9840 & 0.8694 \\
\hline & 2009 & 1.9068 & 0.9840 & 0.9900 & 1.0125 & 0.8947 \\
\hline & 2010 & 1.9946 & 0.9950 & 0.9963 & 1.0344 & 0.9099 \\
\hline & 2011 & 2.0757 & 1.0050 & 1.0019 & 1.0571 & 0.9349 \\
\hline & 2012 & 2.1598 & 1.0140 & 1.0074 & 1.0794 & 0.9727 \\
\hline & 2013 & 2.2881 & 1.0450 & 1.0202 & 1.0838 & 1.0462 \\
\hline & 2014 & 2.3936 & 1.0560 & 1.0269 & 1.1119 & 1.1099 \\
\hline & 2015 & 2.5021 & 1.0670 & 1.0341 & 1.1408 & 1.1283 \\
\hline & 2016 & 2.5925 & 1.0770 & 1.0409 & 1.1657 & 1.1039 \\
\hline & 2017 & 2.6514 & 1.0870 & 1.0475 & 1.1884 & 1.0674 \\
\hline \multirow[t]{16}{*}{ Regional bank I } & 2002 & 1.0978 & 0.9307 & 0.9603 & 0.8823 & 0.7802 \\
\hline & 2003 & 1.1464 & 0.9015 & 0.9376 & 0.8972 & 0.7792 \\
\hline & 2004 & 1.1740 & 0.8904 & 0.9274 & 0.9059 & 0.7780 \\
\hline & 2005 & 1.1941 & 0.8853 & 0.9216 & 0.9125 & 0.7763 \\
\hline & 2006 & 1.2106 & 0.8829 & 0.9180 & 0.9184 & 0.7745 \\
\hline & 2007 & 1.2231 & 0.8819 & 0.9154 & 0.9235 & 0.7732 \\
\hline & 2008 & 1.2317 & 0.8816 & 0.9135 & 0.9275 & 0.7729 \\
\hline & 2009 & 1.2371 & 0.8819 & 0.9122 & 0.9305 & 0.7720 \\
\hline & 2010 & 1.2436 & 0.8827 & 0.9114 & 0.9333 & 0.7705 \\
\hline & 2011 & 1.2494 & 0.8836 & 0.9108 & 0.9355 & 0.7685 \\
\hline & 2012 & 1.2556 & 0.8847 & 0.9104 & 0.9376 & 0.7658 \\
\hline & 2013 & 1.2612 & 0.8859 & 0.9102 & 0.9394 & 0.7637 \\
\hline & 2014 & 1.2680 & 0.8872 & 0.9100 & 0.9416 & 0.7618 \\
\hline & 2015 & 1.2744 & 0.8886 & 0.9100 & 0.9435 & 0.7594 \\
\hline & 2016 & 1.2795 & 0.8898 & 0.9100 & 0.9450 & 0.7607 \\
\hline & 2017 & 1.2822 & 0.8905 & 0.9100 & 0.9463 & 0.7612 \\
\hline
\end{tabular}


Table 8 (continued)

\begin{tabular}{lllllll}
\hline Bank category & Year & EVA & FISIM & TC & SI & TI \\
\hline Regional bank II & 2002 & 0.9907 & 0.9437 & 0.9863 & 0.8810 & 0.9844 \\
& 2003 & 1.0468 & 0.9164 & 0.9563 & 0.8657 & 0.9678 \\
& 2004 & 1.0927 & 0.9106 & 0.9435 & 0.8671 & 0.9728 \\
& 2005 & 1.1320 & 0.9077 & 0.9336 & 0.8707 & 0.9681 \\
& 2006 & 1.1668 & 0.9079 & 0.9270 & 0.8779 & 0.9631 \\
2007 & 1.2006 & 0.9096 & 0.9208 & 0.8895 & 0.9574 \\
& 2008 & 1.2204 & 0.9122 & 0.9167 & 0.9015 & 0.9631 \\
& 2009 & 1.2291 & 0.9154 & 0.9138 & 0.9153 & 0.9634 \\
2010 & 1.2430 & 0.9184 & 0.9113 & 0.9253 & 0.9649 \\
& 2011 & 1.2552 & 0.9216 & 0.9093 & 0.9352 & 0.9616 \\
& 2012 & 1.2620 & 0.9273 & 0.9106 & 0.9473 & 0.9494 \\
& 2013 & 1.2824 & 0.9303 & 0.9078 & 0.9587 & 0.9337 \\
2014 & 1.2968 & 0.9329 & 0.9062 & 0.9691 & 0.9370 \\
2015 & 1.3073 & 0.9347 & 0.9052 & 0.9767 & 0.9383 \\
2016 & 1.3179 & 0.9372 & 0.9041 & 0.9854 & 0.9268 \\
2017 & 1.3270 & 0.9396 & 0.9033 & 0.9940 & 0.9329 \\
\hline
\end{tabular}

EVA Economic Value Added, FISIM Financial Intermediation Services Indirectly Measured, TC total credit, S/ security investment, $T /$ total investment (total interest income)

\section{Acknowledgements}

Not applicable.

Authors' contributions

AJJ designed, analyzed, and drafted this research work. While IH provided the source data, translated the data from Japanese to English, supervise and redraft the paper. Both authors read and approved the final manuscript.

\section{Funding}

This research was supported by JSPS KAKENHI Grant Number 19J10715. Only financial cost related to this research was covered by the grant. All other aspects of the research; from the design to the final draft, were the authors' work.

\section{Availability of data and materials}

The datasets generated and analyzed for this research work are available in the Japan Bankers Association repository (https://www.zenginkyo.or.jp/en/).

\section{Competing interests}

The authors declare that they have no competing interests.

Received: 4 May 2020 Accepted: 23 June 2021

Published online: 08 July 2021

\section{References}

Aduba JJ, Asgari B (2020) Productivity and technological progress of the Japanese manufacturing industries, 2000-2014: estimation with data envelopment analysis and log-linear learning model. Asia-Pac J Reg Sci 4(2):343-387. https:// doi.org/10.1007/s41685-019-00131-w

Amici A, Fiordelisi F, Masala F, Ricci O, Sist F (2013) Value creation in banking through strategic alliances and joint ventures. J Bank Finance 37(5):1386-1396. https://doi.org/10.1016/j.jbankfin.2012.03.028

Argote L (2012) Organizational learning curves: overview. In: Organizational learning: creating, retaining and transferring knowledge, 2nd edition. Springer, pp 10-11. https://doi.org/10.4135/9781412952613.n372

Argote L, Ingram P (2000) Knowledge transfer: a basis for competitive advantage in firms. Organ Behav Hum Decis Process 82(1):150-169. https://doi.org/10.1006/obhd.2000.2893

Arnould WAB, Anjan VT (1997) Banking scope and financial innovation. Rev Financ Stud 10(4):1099-1131

Arrow KJ (1962) The economic implications of learning by doing. Rev Econ Stud. https://doi.org/10.2307/2295952 
Asgari B, Yen LW (2009) Accumulated knowledge and technological progress in terms of learning rates: a comparative analysis of the manufacturing industry and the service industry in Malaysia. Asian J Technol Innov. https:// doi.org/10.1080/19761597.2009.9668674

Asongu SA, Odhiambo NM (2019) Size, efficiency, market power, and economies of scale in the African banking sector. Financ Innov. https://doi.org/10.1186/s40854-019-0120-x

Badiru AB (1992) Computational survey of univariate and multivariate learning curve models. IEEE Trans Eng Manag. https://doi.org/10.1109/17.141275

Bahk B, Gort M (1993) Decomposing learning by doing in new plants. J Polit Econ. https://doi.org/10.1086/261888

Balasubramanian N, Lieberman MB (2010) Industry learning environments and the heterogeneity of firm performance. Strateg Manag J 31:390-412. https://doi.org/10.1002/smj.816

Barnett WP, Greve HR, Park DY (1994) An evolutionary model of organizational performance. Strateg Manag J 15:11-28

Baum JAC, Ingram P (1998) Survival-enhancing learning in the Manhattan Hotel Industry, 1898-1980. Manage Sci 44(7):996-1016. https://doi.org/10.1287/mnsc.44.7.996

Benston GJ, Smith CW (1976) A transactions cost approach to the theory of financial intermediation. J Financ 31(2):215-231

Berger AN, Humphrey DB (1992) Measurement and efficiency issues in commercial banking. In: Output measurement in the service sectors (Ed, Issue January, pp. 245-300). University of Chicago Press. http://ideas.repec.org/h/nbr/ nberch/7237.html

Berger AN, Mester LJ (1997) Inside the black box: what explains differences in the efficiencies of financial institutions? J Bank Finance 21(7):895-947. https://doi.org/10.1016/50378-4266(97)00010-1

Besanko D, Dranove D, Shanley M, Schaefer S (2013) The horizontal boundaries of the firm. In: Economics of strategy, 6th ed. Wiley, pp 61-93

BoJ (2018) Financial system report. https://www.boj.or.jp/en/research/brp/fsr/data/fsr180419a.pdf

Born B, Breitung J (2016) Testing for serial correlation in fixed-effects panel data models. Econ Rev 35(7):1290-1316. https://doi.org/10.1080/07474938.2014.976524

Bossone B, Lee J (2004) In finance, size matters: the "systemic scale economies" hypothesis. IMF Staff Pap 51 (1):19-46

Bush G (2015) Learning by banking: testing for experience effects in the financial sector. SSRN Electron J. https://doi. org/10.2139/ssrn.2688578

Clark JA (1984) Estimation of economies of scale in banking using a generalized functional form. J Money Credit Bank 16(1):53-68

Clark JA (1988) Economies of scale and scope at depository financial institution: a review of the literature. Econ Rev September/October, 16-33

Darr ED, Argote L, Epple D (1995) The acquisition, transfer, and depreciation of knowledge in service organizations: productivity in franchises. Manag Sci. https://doi.org/10.1287/mnsc.41.11.1750

DeYoung R (2002) Learning-by-Doing, Scale Efficiencies, and Financial Performance at Internet-Only Banks (WP-0106). https://doi.org/10.2139/ssrn.282721

Drake L, Hall MJ, Simper R (2006) The impact of mircroeconomic and regulatory factors on bank efficiency; a nonparametric analysis of Hong Kong's banking system. J Bank Finance 30:1443-1466

Driscoll JC, Kraay AC (1998) Consistent covariance matrix estimation with spatially dependent panel data. Rev Econ Stat

Fiol M, Lyles M (1985) Organizational learning. Acad Manag Rev 10(4):803-813. https://doi.org/10.31686/ijier.vol7.iss4. 1427

Fiordelisi F (2007) Shareholder value efficiency in European banking. J Bank Finance. https://doi.org/10.1016/j.jbank fin.2006.10.021

Fiordelisi F, Molyneux P (2010) The determinants of shareholder value in European banking. J Bank Finance. https:// doi.org/10.1016/j.jbankfin.2009.11.018

Grigorian DA, Manole V (2006) Determinants of commercial bank performance in transition: an application of data envelopment analysis. Comp Econ Stud 48:497-522

Harimaya K (2018) The effects of consolidation on bank cost savings: evidence from Japanese regional banks. Jpn World Econ. https://doi.org/10.1016/j.japwor.2018.03.002

Hoechle D (2007) Robust standard errors for panel regressions with cross-sectional dependence. Stata J 7(3):281-312

Hughes J, Mester $L J$ (2014) Measuring the performance of banks: theory, practice, evidence, and some policy implications. In: The Oxford handbook of banking, 2nd ed. Oxford University Press, Oxford. https://doi.org/10.1093/oxfor dhb/9780199688500.013.0010

Hughes JP, Mester LJ, Moon CG (2001) Are scale economies in banking elusive or illusive? Evidence obtained by incorporating capital structure and risk-taking into models of bank production. J Bank Finance. https://doi.org/10.1016/ S0378-4266(01)00190-X

Irwin DA, Klenow PJ (1994) Learning-by-doing spillovers in the semiconductor industry. J Polit Econ. https://doi.org/10. $1086 / 261968$

Kamei, K. (2019). Japan to crack down on struggling regional banks. Nikkei Asian Review. https:/asia.nikkei.com/Business/ Companies/Japan-to-crack-down-on-struggling-regional-banks

Karaoz M, Albeni M (2005) Dynamic technological learning trends in Turkish manufacturing industries. Technol Forecast Soc Chang. https://doi.org/10.1016/j.techfore.2004.09.005

Kim JY, Kim JY, Miner AS (2009) Organizational learning from extreme performance experience: the impact of success and recovery experience. Organ Sci 20(6):958-978. https://doi.org/10.1287/orsc.1090.0439

Kimball RC (1998) Economic profit and performance measurement in banking. New Engl Econ Rev 35-53. https://www. bostonfed.org/publications/new-england-economic-review/1998-issues/issue-july-august-1998/economic-profitand-performance-measurement-in-banking.aspx

Kmenta J (1986) Elements of econometrics, 2nd edn. Macmillan, London

Kou G, Chao X, Peng Y, Alsaadi FE, Herrera-Viedma E (2019) Machine learning methods for systemic risk analysis in financial sectors. Technol Econ Dev Econ 25(5):716-742. https://doi.org/10.3846/tede.2019.8740 
Krawczyk MK (2005) Change and crisis in the Japanese banking industry. In: Institutional and technological change in Japan's economy: past and present, pp 120-139. https://doi.org/10.4324/9780203028018

Lapré MA, Nembhard IM (2010) Inside the organizational learning curve: understanding the organizational learning process. Found Trends Technol Inf Oper Manag 4(1):1-103. https://doi.org/10.1561/0200000023

Lapré MA, Van Wassenhove LN (2001) Creating and transferring knowledge for productivity improvement in factories. Manag Sci. https://doi.org/10.1287/mnsc.47.10.1311.10264

Levitt SD, List JA, Syverson C (2013) Toward an understanding of learning by doing: evidence from an automobile assembly plant. J Polit Econ. https://doi.org/10.1086/671137

Miyakawa D, Inui T, Shoji K (2011) Productivity of banks and its impact on the capital investments of client firms. https:// www.rieti.go.jp/jp/publications/dp/11e016.pdf

Mörttinen L (2005) Banking sector output and labour productivity in six European countries. SSRN Electron J. https://doi. org/10.2139/ssrn.325482

Munteanu A, Brezeanu P (2012) Do Romanian banking institutions create shareholder value? Procedia Econ Finance. https://doi.org/10.1016/s2212-5671(12)00133-5

NRI (2020) Financial services in Japan. Nomura Research Institute, Ltd. https://www.nri.com/-/media/Corporate/en/Files/ PDF/knowledge/publication/jfb/FINB_2019_2020_eng_final.pdf?la=en\&hash=2022512A9C3441FB2A9E46C64 F882D782EE882B7

Ogawa K, Kitasaka S (2000) Bank lending in japan: its determinants and macroeconomic implications. Crisis Change Jpn Financ Syst. https://doi.org/10.1007/978-1-4615-4395-4_7

Parks RW (1967) Efficient estimation of a system of regression equations when disturbances are both serially and contemporaneously correlated. J Am Stat Assoc. https://doi.org/10.1080/01621459.1967.10482923

Pesaran MH (2015) Testing weak cross-sectional dependence in large panels. Econ Rev 34(6-10):1089-1117. https://doi. org/10.1080/07474938.2014.956623

Pramongkit P, Shawyun T, Sirinaovakul B (2000) Analysis of technological learning for the Thai manufacturing industry. Technovation 20(4):189-195. https://doi.org/10.1016/S0166-4972(99)00125-X

Pramongkit P, Shawyun T, Sirinaovakul B (2002) Productivity growth and learning potentials of Thai industry. Technol Forecast Soc Chang 69(1):89-101. https://doi.org/10.1016/S0040-1625(99)00088-8

Radić N (2015) Shareholder value creation in Japanese banking. J Bank Finance. https://doi.org/10.1016/j.jbankfin.2014. 09.014

Ramanarayanan S (2011) Does practice make perfect: an empirical analysis of learning-by-doing in cardiac surgery. SSRN Electron J. https://doi.org/10.2139/ssrn.1129350

Shen F, Zhao X, Kou G (2020) Three-stage reject inference learning framework for credit scoring using unsupervised transfer learning and three-way decision theory. Decis Support Syst 137(June):113366. https://doi.org/10.1016/j.dss. 2020.113366

Thampy A, Baheti R (2012) Economic value added in banks and development financial institutions. SSRN Electron J. https://doi.org/10.2139/ssrn.2162770

Uyemura DG, Kantor CC, Pettit JM (1996) EVAR for banks: value creation, risk management, and profitability measurement. J Appl Corp Financ. https://doi.org/10.1111/j.1745-6622.1996.tb00118.x

Wickens MR, Kmenta J (1972) Elements of econometrics. Economica. https://doi.org/10.2307/2552662

Wooldridge JM (2002) Econometric analysis of cross section and panel data. MIT Press, Cambridge, Mass

Wright TP (1936) Factors affecting the cost of airplanes. J Aeronaut Sci 3(4):122-128. https://doi.org/10.2514/8.155

Zollo M, Singh H (2004) Deliberate learning in corporate acquisitions: post-acquisition strategies and integration capability in U.S. bank mergers. Strat Manag J 25(13):1233-1256. https://doi.org/10.1002/smj.426

\section{Publisher's Note}

Springer Nature remains neutral with regard to jurisdictional claims in published maps and institutional affiliations.

\section{Submit your manuscript to a SpringerOpen ${ }^{\circ}$ journal and benefit from:}

- Convenient online submission

- Rigorous peer review

- Open access: articles freely available online

- High visibility within the field

- Retaining the copyright to your article

Submit your next manuscript at $\boldsymbol{\nabla}$ springeropen.com 